NBER WORKING PAPER SERIES

\title{
LOOSE KNOTS: \\ STRONG VERSUS WEAK COMMITMENTS \\ TO SAVE FOR EDUCATION IN UGANDA
}

\author{
Dean Karlan \\ Leigh L. Linden \\ Working Paper 19863 \\ http://www.nber.org/papers/w19863 \\ NATIONAL BUREAU OF ECONOMIC RESEARCH \\ 1050 Massachusetts Avenue \\ Cambridge, MA 02138 \\ January 2014, Revised January 2023
}

\begin{abstract}
We are grateful for the assistance of a number of individuals and organizations without whom this project could not have been successfully completed. Caton Brewster, Carl Brinton, Sarah Kabay, Sana Khan, Selvan Kumar, Hart Lang, Kelsey Larson, Doug Parkerson, Pia Raffler, Amol Raswan, Elana Safran and Glynis Startz from Innovations for Poverty Action all provided valuable assistance with the research or project management. We gratefully acknowledge the financial support of the Yale Savings and Payments Research Fund at Innovations for Poverty Action, sponsored by a grant from the Bill \& Melinda Gates Foundation. The United States Agency for International Development (Development Innovations Venture Award AID-OAA-G-12-00008) generously provided additional funding for the project. All opinions are those of the authors, and not necessarily that of any of the funders or collaborating institutions, nor of the National Bureau of Economic Research.
\end{abstract}

NBER working papers are circulated for discussion and comment purposes. They have not been peer- reviewed or been subject to the review by the NBER Board of Directors that accompanies official NBER publications.

(C) 2014 by Dean Karlan and Leigh L. Linden. All rights reserved. Short sections of text, not to exceed two paragraphs, may be quoted without explicit permission provided that full credit, including $(\odot$ notice, is given to the source. 
Loose Knots: Strong versus Weak Commitments to Save for Education in Uganda

Dean Karlan and Leigh L. Linden

NBER Working Paper No. 19863

January 2014, Revised January 2023

JEL No. D12,D91,I21,O12

\begin{abstract}
$\underline{\text { ABSTRACT }}$
Commitment devices offer an opportunity to restrict future choices. However, strict commitments may deter participation. Using a school-based commitment savings program for children to save for educational expenses in Uganda, we compare an account fully-committed to school expenses to an account with a weaker commitment (funds withdrawn in cash, rather than a voucher). Children save more in the weaker commitment treatment arm, and when combined with parental outreach spend more on educational supplies and score 0.11 standard deviations higher on math and language test scores. The fully-committed account yields no such educational improvements, and neither account finds impacts on secondary or downstream outcomes such as attendance, enrollment, or non-cognitive skills.
\end{abstract}

\author{
Dean Karlan \\ Kellogg Global Hub \\ Northwestern University \\ 2211 Campus Drive \\ Evanston, IL 60208 \\ and CEPR \\ and also NBER \\ dean.karlan@gmail.com \\ Leigh L. Linden \\ Department of Economics \\ The University of Texas at Austin \\ 2225 Speedway \\ BRB 1.116, C3100 \\ Austin, Texas 78712 \\ and NBER \\ leigh.linden@austin.utexas.edu
}


“Make it easy" - Richard Thaler, co-author of Nudge: Improving Decisions about Health, Wealth, and Happiness (Clement 2013)

\section{Introduction}

A commitment device offers empowerment through restraint. Through such devices, a commitment-maker exercises their agency up-front in order to limit their range of future choices. In self-aware moments, individuals may choose to adopt these restrictions to resist future temptation or fend off social or filial pressures that are at odds with the commitment maker's goals. Indeed, prior research finds demand for commitment savings accounts that restrict access to one's money in order to help with self-control issues (Ashraf, Karlan, and Yin 2006; Brune et al. 2016; Dupas and Robinson 2013; Giné et al. 2018), and other research finds demand for commitment devices in other domains.

This project began after qualitative research on household finance in Uganda identified saving for school fees and supply costs as a key barrier for families. ${ }^{1}$ We tackle three primary questions within the context of an educational savings intervention. First, a program evaluation question: can a commitment savings program that encourages students to save improve student performance through increased educational expenditures? We discuss below but note this program offers not only a commitment savings account but also weekly opportunities to deposit following class discussions. Second, will the commitment savings account work better with strict rule on how the accumulated funds are spent or a flexible rule? And third, does the savings-oriented commitment device change actual educational expenditures or instead does it get unwound through off-setting behavior?

The specifics of what one means by "commitment" on a commitment savings account varies considerably, and may generate correspondingly varied impacts on account opening, total deposits, total withdrawals, and perhaps most importantly ultimate expenditure and investment decisions. The commitment versus flexibility tradeoff exists across many points in the savings and spending process (see Amador, Werning, and Angeletos (2006) for a theoretical analysis of the overall tradeoff between commitment and flexibility). In developing countries, prior work has tested soft savings commitments versus control (Dupas and Robinson 2013), hard savings commitments versus control (Duflo, Kremer, and Robinson 2011); and, in the United States, prior work has tested soft commitment (non-binding pledge and a planning exercise) compared to a hard commitment that restricted withdrawals (Burke, Luoto, and Perez-Arce 2017), as well as harshness of early withdrawal penalties from commitment savings accounts (Beshears et al. 2017). Alas given the challenge in categorizing product features into simplistic "strong" and "weak", and the

\footnotetext{
${ }^{1}$ The initial role for the qualitative work was to collaborate with an insurance company and identify missing insurance products. Although the insurance work did not proceed, the dominance of low savings for school in the focus groups led the researchers to this project.
} 
changes in context (health to agriculture), it is difficult drawing generalized claims about soft versus hard commitments.

We focus here on one key dimension: whether the funds deposited are locked in for a specific "good" expenditure, or if individuals have freedom to spend withdrawals as they wish in a setting in which the "good" item is made easily available. ${ }^{2}$ We define "hard" as one which locks spending in for specific purposes and "soft" as one which is labelled as such but not locked into such expenditures. In a similar Dupas and Robinson (2013) study, participants believed their lockboxes had to be spent on health, even though it did not; in this sense however we believe it is accurate to equate their health lockbox to the soft commitment account in our context, since similarly there was no requirement to spend it as such but alas that is how people used the funds.

In theory the tradeoffs are clear: a strong commitment device may be more effective in enforcing the behavior of the future self, but the current self may be less likely to participate in the contract at all. An individual may want to commit in some, but not all, future states of the world, since emergencies do happen. The challenge is designing a contract in which a third party has the right level of enforcement discretion. This tension is highlighted in related work by John (2020), which argues that penalties for failing to complete commitments may be too weak for a certain range of the naïve, because the unfortunate case occurs too often (punishment for failure to complete the contract). If an individual cannot trust any third parties with that discretion, a self-enforcing commitment contract may work instead. In such a contract, the increased price of vice is derived from psychic costs, i.e., disappointment with oneself and one's lack of adherence to a plan. This is akin to a model put forward by Benabou and Tirole (2004) on how personal rules can shift later behavior, and also could be construed as a test of whether "mental accounting" can be a policy instrument that induces behavior change (Shefrin and Thaler 1992).

Our third question examines whether commitment devices get unwound through offsetting behavior (Karlan, Ratan, and Zinman 2014). More money spent from a commitment account for a particular purpose may simply crowd-out spending for that same purpose with funds from other sources. By examining how actual expenditures change for the particular purpose, rather than merely observing whether savings increases, we are able to make stronger statements about welfare outcomes, similar to Ashraf et al (2010) with respect to household durable goods purchases and Dupas and Robinson (2013) with respect to health investments.

We examine these questions in the context of a school-based commitment savings account in Uganda. Specifically, we test whether a stronger versus a weaker savings commitment device helps children and their families save more, spend more on educational expenses, and achieve higher test scores. Relative to the economics of education literature, we thus gain a better understanding

\footnotetext{
${ }^{2}$ Clearly in a perfect market, specifically one with zero transaction costs, this would make no difference: any items purchased with the locked-in commitment account could simply be sold in exchange for the most desirable item for the same value. In our market, supplies and services associated with primary education in Uganda, there are significant enough transaction costs to make such an exchange quite costly, and thus the original expenditure sticky.
} 
of the education production process (Kremer and Holla 2009), building on a growing body of evidence demonstrating the possibly significant effects of basic school supplies - notebooks, uniforms, workbooks, etc. - on student performance (Das et al. 2013; Hidalgo et al. 2013) and parental involvement (Avvisati et al. 2013). Second, the results build on existing evidence of the importance of savings constraints for educational expenses (Barrera-Osorio et al. 2011) as well as mechanisms for tying resources to educational expenses (De Arcangelis et al. 2014). ${ }^{3}$

We evaluate the intervention ("Supersavers") as follows: working with a local nonprofit organization Private Education Development Network (PEDN) in the Busoga sub-region of the Eastern region of Uganda, and Innovations for Poverty Action (IPA), we randomly assigned 136 primary schools to one of three groups: a strong commitment savings account (funds could be withdrawn no earlier than the end of the term, and had to be spent on educational items through a voucher that we provided), a weak commitment savings account (funds could be withdrawn no earlier than the end of the term, but were available in cash, to be spent as individuals wished) ${ }^{4}$, or control. For both treatments, students could deposit cash into an account. At the end of each trimester they were able to use their cash or vouchers to purchase school supplies at a fair. ${ }^{5} \mathrm{We}$ thus compare a stricter commitment device and a weaker "make it easy" nudge of individuals towards a specific behavior (Thaler and Sunstein 2009). Although the accounts were described as the students' accounts, we cannot rule out that some of the funds were considered parental funds and managed as such by the family. ${ }^{6}$ We developed a brief teacher training component and also coordinated the transfer of money from a savings box held at the school to a local bank for safekeeping. One year into the implementation, we implemented one sub-treatment in half of the treatment schools, a parental involvement workshop.

The first stage is critical and revealing: students deposit significantly more money into the soft commitment savings account than the hard commitment savings account. And, for those with the parental outreach sub-treatment, the additional money deposited into the account leads to higher investment in school supplies, which then in turn leads to higher test scores. We find a 0.10 standard deviation (se=0.04) improvement in overall scores; this includes effects on each of the covered subjects: grammar ( 0.13 standard deviations, se $=0.04$ ), reading $(0.11$ standard deviations, $\mathrm{se}=0.05$ ), and math ( 0.01 standard deviation, se $=0.05$ ). The implication for the school production

\footnotetext{
${ }^{3}$ It is interesting to note that, while we find that relaxing savings constraints improves educational outcomes, we find improvements in academic performance rather than participation. This contradicts the results of Barrera-Osorio et al. (2011) which finds that distributing funds at the time that families have to pay enrollment expenses improves enrollment rates. The difference may, in part, be due to the fact that unlike Uganda, Colombian schools still charged official fees for enrollment.

${ }^{4}$ The weak commitment treatment arm is thus most similar to the SEED account in Ashraf et al (2006), i.e., a commitment merely to not withdraw funds until a certain future point in time.

${ }^{5}$ Note that control schools did not receive a fair. Thus analysis of "any treatment" is also bundling the presence of these fairs when examining school supplies and thus test score outcomes. However, we observe no positive treatment effect on school supplies for the voucher treatment arm, thus we conclude that the fairs themselves did not have an observable direct treatment effect.

${ }^{6}$ As we show below, both the children and other family members contribute to the accounts, raising the possibility that multiple household mechanisms are involved.
} 
function is simple: for a student to learn basic skills, having a pen, paper, and workbook matters. Furthermore, the treatment effect on educational outcomes is sizable, as large as many direct educational interventions, and consistent with other estimates of the effects of such supplies (Das et al. 2013) We find no effect on student participation (either attendance or enrollment) or on a set of non-cognitive outcomes.

One critical gap we leave in our understanding of the underlying mechanics: whose money went into the accounts, the child's or the parent's? About half of our participating students reports engaging in some work and saving some from the money earned from work. This question muddles the ability to assert that the children (versus the parents) had time inconsistent preferences or if, on the other hand, the account shifted power across individuals with different preferences within the household. This is true, of course, in most studies on savings of individuals who live within a household. For example, in a typical “commitment savings” account test (e.g., see Ashraf, Karlan, and Yin 2006; Dupas and Robinson 2013; Brune et al. 2016), accounts are offered to individuals, and outcomes tracked at some combination of individual and household. Yet given fungibility of money within the household, it is difficult if not impossible to assert the source of the deposited funds. Because of the power dynamics between parent and child, there is a particular poignancy to this gap in our setting, yet the gap exists for any study of a savings intervention which targets individuals which live within a household of multiple adults.

\section{Background}

\section{A. Ugandan Primary Education System}

Uganda abolished most primary school fees in $1997 .^{7}$ In the same year, the gross primary enrollment rate ${ }^{8}$ ballooned from 87 percent in the early 1990s, to 123 percent in 1997. Between 1996 and 1997, 2.3 million children enrolled in primary school, increasing total enrollment to 5.7 million (Murphy, Bertoncino, and Wang 2002).

Unfortunately, while most children now enroll in primary school, the majority fail to graduate. In 2008, for example, the gross enrollment rate ${ }^{9}$ in lower secondary was 33 percent- 11 percentage points below the average for Sub-Saharan Africa (UNESCO 2013). The transition from primary to secondary is a challenge, as in many countries. However, the majority do not complete primary school. As of 2010, only 32 percent of students entering primary school completed the seventh grade (“Opportunities Lost: The Impact of Grade Repetition and Early School Leaving” 2012).

\footnotetext{
${ }^{7}$ Initially, up to four children per family could attend school without paying tuition fees (Murphy, Bertoncino, and Wang 2002).

${ }^{8}$ The gross primary school enrollment ratio is the ratio of the number of enrolled primary school children, regardless of age, to the total number of primary school-aged children in the population.

${ }^{9}$ The gross enrollment rate for lower secondary school is the ratio of the number of children enrolled in lower secondary school regardless of age relative to the total number of children in the population who are of age to attend secondary school.
} 
While the poor quality of primary education is a likely factor (Piper 2010), ${ }^{10}$ students still face financial barriers. While students no longer pay enrollment fees, they do face other expenses. Many schools require uniforms, and families are responsible for providing food and school supplies, such as paper, writing instruments, and workbooks. See Appendix Table 1 for a summary of educational fees and expenses expected of households. With the approval of the parent-teacher association and school management committee, schools can also charge fees for ancillary services such as supplementary lessons, practice exams and feeding programs. Official policy prohibits preventing a child from enrolling due to an inability to pay, but the majority of dropouts cite financial concerns. In our baseline survey described below, families paid an average of 5,790 UGX (2.30 USD) to send a child to school for a year, 0.5 percent of Uganda's per capita income in 2010 (UN data 2013).

Confusion and suspicion create additional complications. As we discovered through qualitative interviews and feedback from parents, politicians try to drum up support by claiming school fees are illegal. The terms "universal" and "free" education are sometimes used interchangeably. Many parents do not understand the official financing rules. Some believe that the government should provide for all school related expenses. Finally, rumors of corruption can make even knowledgeable parents reluctant to pay.

\section{B. Description of the Intervention}

To facilitate families' and children's saving for school, we evaluated four variations of a schoolbased savings program. The intervention had two primary objectives. First, it sought to facilitate and encourage the practice of children saving for education, and through saving, improve overall academic performance and support students' continued enrollment. The program targeted students in grades five, six and seven, i.e. the last three years of primary school, in order to target students at high risk for dropping out of school. ${ }^{11}$ At baseline, the mean student age was 12 (sd dev $=1.52$ ).

We developed and implemented the programs in partnership with the Private Education Development Network (PEDN). PEDN is a Ugandan non-profit organization focusing on youth financial and entrepreneurial education. PEDN comprises five full and part time employees, often supplemented by project specific staff hired as needed. For the savings programs, IPA worked with PEDN to hire a local implementation team of about 10 people. ${ }^{12}$

Each treatment variation included the same core component: a savings account administered through the school, and a program to support and encourage children to use the accounts. During

\footnotetext{
${ }^{10}$ The dramatic increases in enrollment have strained existing resources. In the average school in 2005, three children had to share the same textbook and 94 children crammed into a single classroom (Independent Evaluation Group (IEG) 2007).

${ }^{11}$ Uganda follows a 7+2+2 grade structure. Students attend primary school for seven years followed by two years each of lower and then upper secondary school.

${ }^{12}$ This includes only those individuals hired to implement the described programs. It does not include the research staff who conducted the surveys and monitoring visits described below.
} 
an introductory meeting, the implementation team described the program to a joint meeting of the Parent Teacher Associate, the School Management Committee, and other interested parents. If they all voted to participate, we provided each school with metal lock boxes. A designated teacher assisted by student-elected ${ }^{13}$ representatives from each class then managed the program. The implementation team conducted weekly visits to each school to encourage saving and to assist with accounting procedures. Interested students received a passbook in which their individual savings were recorded, and the designated teacher and the implementation team maintained an official register. Depending on a school's preference, students then deposited money into the lockboxes on a daily or weekly basis.

To provide security and transparency, two padlocks secured each box. Parents elected a representative to keep the key to one lock, while the bank held the other. At the end of each trimester, ${ }^{14}$ the two key holders opened the box. The bank representative provided a deposit slip and deposited the funds into the school's account. ${ }^{15}$ The accounts did not earn interest. Inflation varied but averaged around $10 \%$ in this time period, thus the accounts had a negative real interest rate. After the break between trimesters, the implementation team and bank representatives returned to the school for the payout of the funds. Two representatives signed a withdrawal slip to confirm the withdrawal. The designated teacher, student representatives and our team then distributed the money according to the savings register. At the same time, the implementation team organized a small market at each school where students could purchase school supplies or school services such as practice exams or tutoring sessions (most of the funds went to school supplies, although detailed data are unfortunately not available). ${ }^{16}$

Thus in net, treatment effects from the program (irrespective of variations discussed in a moment) compared to control schools could be a result of several factors. The commitment device is motivated by theories about time inconsistent preferences, but the weekly meetings also serve as a mere reminder to save. Reminders have been shown to generate higher savings, albeit on a sample of adults (Karlan et al. 2016). The meetings also constituted effectively curriculum, i.e. lessons from the school about the importance of savings. In an evaluation of an in-school program to promote savings in Ghana, based on a program by Aflatoun, school children were found to save more in school but no downstream effects were found on attitudes, aggregate savings, or education outcomes (Berry, Karlan, and Pradhan 2018). One study is of course not dispositive, particularly given it is a different curriculum and setting, and thus it is important to note that the program could

\footnotetext{
${ }^{13}$ The Ugandan educational system classifies children enrolled in primary school as "pupils" and those in secondary school as "students". In this article, we refer to all enrolled children as students.

${ }^{14}$ The academic year starts in February and follows a trimester system. Schools run for 12 weeks at a time. Students receive a three week break after the first and second terms, and schools are closed in December, January and February. ${ }^{15}$ Working with the bank, FINCA Uganda, we designed an account for the intervention modeled on a traditional group savings account. We also provided the minimum 5,000 UGX deposit and worked with the school's elected signatories to obtain the documentation required to open the accounts.

${ }^{16}$ Students were allowed to rollover vouchers to future terms, and upon completion of the final year (P7), were allowed to withdraw any remaining balance in cash.
} 
be shifting behavior due to the commitment aspect, attention, or information/signaling mechanisms.

On top of the core treatment above, there were four treatment variations, a 2x2 design: "cash" or "voucher" for the withdrawals, and "Parent Outreach" or "No Parent Outreach".

For the cash treatment arm, students received, in cash, their savings from one trimester at the beginning of the next trimester. They could then spend the funds at their discretion —at the markets provided on the disbursement day (thus "making it easy" to spend on school supplies) or elsewhere. The voucher treatment arm, on the other hand, employed a stronger commitment — students had to buy educational products or services at the market, on the disbursement day. ${ }^{17}$ In both variants, children could also re-deposit their savings for the next trimester.

The Parent Outreach component was implemented halfway through the program as an adaptation based on qualitative feedback from teachers and schools. Specifically, there was demand from parents for more information about the program as well as incorrect beliefs being reported back to us via schools. Due to its potential importance (but cost), we randomized this component, implementing it for half of the treatment schools. The implementation team hosted a meeting for sixth and seventh grade parents. The meetings began by identifying the various stakeholders in primary education, their roles and responsibilities. PEDN then discussed the various ways in which parents could support their children's education. In particular, PEDN explained that in addition to providing a student learning experience, the savings program provided an opportunity for the household. It could be a tool to help families finance their children's education. A snack and soda were provided to encourage attendance.

\section{Design of the Evaluation}

\section{A. Research Design}

Figure 1 depicts the timeline for the randomized controlled trial and data collection. We selected 136 primary schools from the Jinja, Iganga, Mayuge, and Luuka districts of the Busoga Region because they predominantly comprised poor rural and peri-urban schools. We then administered a baseline survey and test during the final trimester of 2009. Finally, we randomly assigned schools to receive either the cash treatment (39 schools), voucher treatment (39 schools), or no treatment

\footnotetext{
${ }^{17}$ Early in the intervention there was concern that the teachers and community members mobilized to manage the supplies fair were marking up prices to take advantage of the situation. To avoid this, the supplies markets were taken over as part of the intervention. In collaboration with a wholesale distributer, prices were set to match typical market prices available to students, and the fairs were organized by the implementing NGOs directly. Managing the fairs as part of the intervention also ensured the essentials supplies were there. This does have implications for scale-up attempts, i.e., whether through explicit management or alternative approach, one likely needs to have a competitive market for supplies available for the students. From the success and volume of sales in the weak-commitment treatment arm, we infer that the mix of products was sufficiently diverse and pricing appropriate that lack of engagement in the strong-commitment treatment arm was not due to lack of trust or the wrong product mix, particularly given the repeat nature of the process.
} 
(58 schools), stratifying by the total normalized score on the baseline exam and by geographic regions called sub-counties. ${ }^{18}$

Following the first randomization, school outreach began. It took two trimesters to recruit the majority of schools, but by the beginning of the third trimester of 2010, 95 percent of the treatment schools had agreed to participate (77 joined, 1 refused). ${ }^{19}$ The school that refused to participate did, however, permit data collection, and is thus included for all analysis in the treatment group.

In 2011, we conducted a second randomization for the parent sensitization program. To isolate the effect of the program while still treating all of the schools, we assigned schools either to the Parent Outreach group who received the intervention in the first trimester of 2011 or to the No Parent Outreach group who received the intervention too late to affect student behavior - immediately before the endline survey in second trimester. Half of the schools in each treatment were assigned to each group. We stratified assignment by the schools' initial treatment group and sub-county, and checked for balance using the demeaned savings rates from 2010.

Finally, we conducted the endline survey and exam during the beginning of the third trimester of $2011 .^{20}$

\section{B. Data}

Appendix Table 2 presents the specifics (year of survey, year of student, sample size) of the three datasets created.

We utilize two samples of students, as well as data at the classroom level. The "Attendance Survey" includes all students present in class at baseline and then tracks their attendance in subsequent rounds of data.

Second, we created a representative, longitudinal sample of students identified prior to treatment assignment (the "Student Survey"). These students were tracked regardless of whether or not they continued to be enrolled in the original schools.

\footnotetext{
${ }^{18}$ In 2010, Uganda included four major jurisdictions called "regions." Spread across the four regions, were 111 "districts." Each district was divided into urban areas known as "municipalities" or rural areas called "counties." Counties were further sub-divided into sub-counties. Depending on the population, a district could have as few as three or as many as thirty or more sub-counties.

${ }^{19}$ When they were not canceled, meetings had to be held with school administrators, the school management committee, and the parent-teacher association for each school. Many were initially reluctant to hold additional meetings.

${ }^{20}$ In 2012, we conducted a second, smaller experiment in which we randomly assigned a fraction of the original control group to receive the cash with sensitization program. We also collected the classroom-level data described below. However, the remaining control group proved too small. The point estimates are consistent with those presented here, but the standard errors are too large to provide meaningful information. These results are available upon request.
} 
The classroom-level data included all classes in grades five, six, and seven. Enumerators counted the number of children present, enrolled and possessing notebooks, math set, uniform, or shoes. ${ }^{21,22}$ We conducted these monitoring visits prior to the randomization as part of the baseline and at least once a trimester after the randomization.

The Student Survey includes 4,716 students who completed a baseline survey and aptitude test prior to the randomization. To identify the students for the second (longitudinal) student sample, we compiled a list of all students of the correct ages and grades in September of 2009 (P4 and P5, so that this constituted the students who would be in P5 and P6 for the start of the study). ${ }^{23}$ Teachers then classified each student using a five-point scale to rate frequency of attendance. In particular, this allowed us to identify students on the rosters who did not attend school. From the set of attending children, we randomly selected 35 students from each school, except for two schools in which we included all students because fewer than 35 students had enrolled.

The baseline survey completed by the students in the longitudinal sample was a 40 minute survey that included questions about their education history, experiences with saving, time preferences, and demographic information. Students also completed an hour-long, 35-question exam covering math, grammar, and reading comprehension. Students in each grade took separate exams based on the national curriculum for their grade. ${ }^{24}$

Students completed an endline survey about two years after the baseline survey. The 40 minute survey included questions about saving behavior, possession of resources like those in the classlevel survey, such as uniforms, books, math sets, and shoes. It also included a 60 minute exam in the same three subjects as the baseline exam. The grade level of the endline exam was based on the students' grade at baseline, and all baseline and endline scores are standardized within grade and subject relative to the contemporaneous control distribution. We tracked students regardless of their enrollment status, finding 3,838 of the original respondents.

Finally, we verified the presence of each student in the longitudinal sample during each class-level monitoring visit. This provided an objective measure of students' attendance rates as well as whether students were still enrolled in school in the appropriate grade.

Unfortunately, we lack two datasets which would have been fruitful, but were not feasible to collect: individual level savings data, and specific purchase decisions from the fairs in which school supplies were sold.

\footnotetext{
${ }^{21}$ The enumerator only counted a student as having each item if the enumerator could see it.

${ }^{22}$ Notebooks cost approximately 200 UGX (0.08 \$USD) each. In Uganda, they are usually called "exercise books.” A math set costs approximately 1,000 UGX (0.40 \$USD) and includes such tools as a ruler, protractor and compass. Uniform and shoes each cost about 6,000 UGX. (2.39 \$USD) They are a traditional school requirement.

${ }^{23}$ For a small number of classes, rosters were unavailable. We had to create a list of students based on the students present in class and information provided by the teacher.

${ }^{24}$ For both the baseline and endline exams, all scores are normalized within grade and subject relative to the contemporaneous control distribution.
} 


\section{Orthogonality of Treatment Assignment and Attrition}

In Table 1, we verify the effectiveness of the randomization in creating observably similar treatment and control groups on average. Each row presents estimates for the indicated baseline characteristic. Columns 1-3 provide the sample size for each variable, ${ }^{25}$ the pooled treatment mean and standard deviation, and the control mean and standard deviation. Column 4 provides the regression estimates of the difference between the combined treatment group and control group, while Columns 5-8 provide regression estimates of the difference between each treatment group and the control group. All differences are estimated using equation (1), controlling for the subcounties in which the schools were stratified.

Overall, the differences are minimal, i.e., the assignment to each treatment is orthogonal to a series of baseline variables. Of the 83 estimates presented, nine are statistically significant: one at the one-percent level, five at the five percent level, and three at the ten percent level. The overall joint test of significance presented in the bottom row is not significant for any treatment group. Most importantly, the magnitudes of the estimated differences are also all relatively small. Regardless, the main specification includes control for baseline value of the outcome variables as well as test scores. In the appendix we then repeat the main tables without these additional controls, and results are qualitatively similar, suggesting that any imbalance at baseline was due to measurement error.

Table 2 analyzes attrition. First, Row 1 presents the basic test for whether treatment led to differential attrition rates overall. Columns 2 and 3 show that we have similar survey completion rates in treatment and control (82 and 81 percent), and Row 1 Columns 5-8 report no differences in attrition rates across the four treatment groups. However, even though the overall attrition rate is not affected by assignment to treatment, differential attrition could result in differences in the analysis sample frame (i.e., those who complete the endline survey, or take the endline exams). To test for this, we replicate Table 1 analysis on various baseline measures (rows 2 onward). The table is organized similarly to Table 1 (except that the classroom variables are omitted, since there is no attrition at the classroom level). Overall, we find no evidence of compositional effects from differential attrition. Only six tests are statistically significant (out of 66, and the only differences from Table 1 are the estimates for days missed per school term and the time preference measures.

\section{Results}

Since the random assignment should ensure the orthogonality of treatment assignment and other student characteristics, our primary specification estimates the treatment effects via ordinary least squares using the following specification:

$$
Y_{i j k}=\alpha+\boldsymbol{\tau}^{\prime} \text { treat }_{j}+\boldsymbol{\delta}^{\prime} \boldsymbol{X}_{i k}+\varepsilon_{i j} .
$$

\footnotetext{
${ }^{25}$ Sample sizes vary because subjects refused to respond to some questions.
} 
The variable $Y_{i j k}$ is the dependent variable of interest. We perform estimates at the student and class level. The index $i$ then represents either the student or class in school $j$ and sub-county $k$. The vector treat $\boldsymbol{t}_{\boldsymbol{j}}$ is a vector of indicator variables for each treatment, and $\boldsymbol{X}_{\boldsymbol{i}}$ is a vector of control variables. For each estimate, we control for baseline test scores in math, reading, and grammar; sub-county fixed effects; and, the baseline value of the outcome if available. We cluster standard errors by the unit of randomization, the school.

First, we assess students' savings behavior. In Table 3, we provide two measures of total program savings over the two years: the total per school and per student (using two measures of the latter). Columns 1-4 provide the average for each research group. Focusing on the 2011 results, and with a less restrictive measure of the student body (attendance at any point during the two year study period), the two cash payout treatment groups produce average per student savings of 3,604 UGX and 2913 UGX in the parent outreach and no parent outreach groups, respectively. Using average attendance, these results approximately double to 4,411 and 3,672, respectively. In comparison, the two voucher treatments, with and without parent outreach, show average savings of 1,262 UGX and 1,511 UGX with a less restrictive measure of attendance; and 1,595 UGX and 1,772 UGX using average attendance. The differences between cash and voucher are statistically significant at the $1 \%$ level for average deposits per school and at the $5 \%$ level for average deposits per student for both measures of attendance (Column 5). On the other hand, the differences between parent and no parent outreach are not statistically significantly different from zero (Column 6). The results for 2010 (Panel A) are similar, albeit with smaller magnitudes.

We draw three conclusions from the savings data. First, the more restrictive savings vehicle, the voucher treatment, generated significantly less savings than the less restrictive cash treatment. Second, for those in either of the savings treatment groups, we find no additional effect of the parent outreach on savings (and the parental outreach treatment was only implemented within the treatment groups, not within the control group, thus we can estimate its treatment effect in an environment with the savings treatments). This supports the upcoming evidence that while the cash treatment arm led to higher savings, the parent outreach component shifted how the funds were spent. ${ }^{26}$

Table 4 examines other key process and intermediate outcomes. First, in Panel A, we examine process outcomes from the program itself, as reported by students in the endline survey. We find that 79 percent of treatment students and only 11 percent of control students were familiar with the Supersavers program. Similarly, 44 percent of treatment group students and only 3 percent of control group students reported saving with Supersavers. There was little difference in program awareness or self-reported participation on the extensive margin across treatment groups. This thus supports the argument that the difference in outcomes is not due to differential marketing or promotion of the program, or differential compliance to experimental protocols, but rather to the

${ }^{26}$ Both parents and children contributed to the accounts. According to the endline survey, 57 percent of children reported having earned the money that they deposited. 
attractiveness of the cash versus voucher condition and the parent outreach. We also observe an increase in self-reported in-school savings, and reduction in self-reported out-of-school savings.

In Panel B and C, we then examine intermediate outcomes, i.e., the possession of school supplies (measured both during classroom visits as well as in the endline survey ${ }^{27}$ ), parental involvement, savings attitudes, and payment of school fees. Analysis of these questions helps to understand the mechanism through which the program worked. We present the results for each, but only find an impact on the possession of school supplies and whether students spent savings on school supplies, suggesting that the other mechanisms are not responsible for the observed impacts, or are poorly measured.

As an indicator of general spending on school related expenses, we collect data on school supplies observable to the survey both in the classroom and endline survey. Panel B presents the results on school supplies that could be observed during classroom visits. The classroom visit school supplies index is normalized with respect to the control group and takes the average of four proportions: proportion of students in the classroom possessing uniforms, notebooks, math sets, and shoes. ${ }^{28}$ In 2010, none of the treatment groups yields statistically significant increases relative to the control group, and in particular the Cash with Parent Outreach treatment estimate is 0.12 standard deviations ( $\mathrm{se}=0.13$ ). However, oddly, relative to each other, the cash parent group is statistically different than the other treatment groups (Column 8). This is partly the result of a negative point estimate for the other treatment groups. Given that the parental outreach did not occur until the end of 2010, the treatment estimate for Cash with Parent Outreach is not statistically significantly different than zero, and the negative point estimates in the other treatment groups are not statistically significant, we consider the differential across treatment groups likely spurious.

For 2011, with an additional year of experience implementing the program and after the parent outreach had been fully launched, the Cash with Parent Outreach treatment arm performs considerably better than control, as well as the other three treatments (both when compared individually, as well as when the other treatments are pooled with control). Column 5 shows a 0.32 standard deviation improvement (se=0.13) in the school supplies index, compared just to control. This result is then reinforced by the endline survey, reported in Panel C: The school supplies index from the self-reported survey also shows in Column 5 a 0.09 standard deviation improvement (se=0.05) compared to control, and a statistically significant improvement relative to the other treatment groups (Column 9). ${ }^{29}$ We do not however observe any statistically significant shifts in

\footnotetext{
${ }^{27}$ If control group households were buying school supplies earlier than treatment schools, because of the savings accounts and fairs, we would on average observe this because the classroom surveys were conducted during the term, not merely at the end of the term.

${ }^{28}$ Appendix Table 4a presents the results for each of the components of this index.

${ }^{29}$ Appendix Tables 4a, 4b and 4c provide the details for each component of the supplies indexes in Panels B and C. The differences seem to be driven primarily by exercise books, although the individual components analysis is less robust statistically.
} 
school fees expenditures (albeit with large standard errors), self-reported absence because of failure to pay school fees, or amount paid for most recent tests. ${ }^{30}$

Panel C reports on data from the endline survey on parental involvement and savings attitudes. Although the school supplies and test score impacts are strongest on the Cash with Parent Outreach treatment cell, we do not observe a direct impact on an index of three questions ${ }^{31}$ regarding parental involvement in the child's education (or the individual components, as reported in Appendix Table 4b). Furthermore, we do not observe changes in a savings attitudes index of seven questions. ${ }^{32}$ This may have implications for long-term change in saving behavior, if one posits that these attitudinal shifts are a necessary component for long-term behavior change, after the active involvement from the NGO and savings program. Alternatively, the measures may be flawed, or the attitudinal changes may be unnecessary; the learned pattern of savings may be possible to change without changing underlying savings attitudes.

Next we turn to test score results in Table 5. We put forward two basic mechanisms here: first, the savings account enables the purchasing of school supplies that are necessary for learning; second, the parental outreach leads the households and children to use the savings accounts to actually spend the saved money on school supplies. This is consistent with the results in Table 4 on the impact on school supplies. And likewise, this mechanism predicts that the Cash with Parent Outreach treatment group should generate the largest (or only) positive impacts. Column 5 indicates that Cash with Parent Outreach improves overall test scores by 0.10 standard deviations (se=0.04). Looking at the components of the test, we find improvements in grammar ( 0.13 standard deviations, $\mathrm{se}=0.04)$ and reading $(0.11$ standard deviation, $\mathrm{se}=0.05)$, but no effect on math $(0.01$ standard deviations, se $=0.05$ ). None of the other three treatment groups generates statistically significant improvements compared to the control group, either overall or for any subject.

\footnotetext{
${ }^{30}$ This pattern of results is consistent with students' reports on the endline survey regarding the disposition of the saved funds. We observe that students in the cash treatment with the parent sensitization report spending 3.6 percent more of the saved funds on school related expenses than students in the cash treatment without the sensitization. This is not a large enough difference to explain our results, but we are skeptical of the accuracy of these self-reported answers. We observe no differences in the amount of the savings used to purchase food or clothing or given to other family members. The increase in school related expenditures primarily comes from "other" expenses. This difference, however, is likely too small to explain all of the observed increase in school supplies, suggesting that the parent sensitization functioned both to divert students' savings and other unsaved household resources towards school supplies (but only in the weak-commitment arm, i.e., the strong commitment rules dissuaded the parents - even if aware of the opportunity - from engaging in such reallocations). Ultimately however we recognize that these are small amounts and self-reported data and thus it is difficult to draw too much inference regarding the source of funds and any such reallocations.

${ }^{31}$ The three questions in the Parental Involvement Index are (1) Student thinks parents are responsible for children's education (2) Has your parent come to your school in the past year? (3) Has your parent seen a report of yours from school in the past year? Appendix Table $4 \mathrm{~b}$ presents the results for each of the components in this index.

32 Savings Attitude Index includes 7 statements each of which the student evaluated on a Likert scale, 1-5. All scales were converted after the fact so that higher on the scale meant more positive attitude toward saving. (1) Saving money is not necessary if you live at home with your family. (2) Saving is a good thing to do. (3) Saving is for adults only. (4) My parents or relatives would be proud of me for saving. (5) Managing to save makes me feel happy with myself. (6) It's better to spend money today than to save it for use in the future. (7) Every time I get money I put away some money for saving. Appendix Table 4b presents the results for each of the components in this index.
} 
However, we do observe a 0.11 reduction in math test scores for the Voucher with Parent Outreach treatment group. We have no hypothesis, aside from this being a spurious result. It is important to note that the magnitude is concerning, since it is almost as negative as the positive treatment effects from the Cash with Parent Outreach treatment arm; however, the aggregate test score is not statistically significant (-0.02 standard deviations, se $=0.04)$, both of the other two components are fairly precise null effects ( 0.02 and -0.00 standard deviations, se $=0.04$ and 0.05 ), and there is no reason to posit a differentially negative effect for math versus other subject areas.

Interestingly, the positive test score results from the Cash with Parent Outreach treatment arm are consistent with Das et al. (2013) which finds similar effects resulting from a \$3 per student increase in student supplies. Both sets of results contrast with the traditional view that resources have limited effects on learning (Kremer and Holla 2009). Appendix Table 6 repeats Table 5 without the controls for baseline individual test scores, and while the coefficients are similar the standard errors (due to omitted control variables for baseline test scores) are higher, and only the grammar test result remains statistically significant.

We also examine whether the improved test scores arises through increased attendance or enrollment, but find no evidence for either. Table 6 Panel A reports results on observed attendance as well as an index of three self-reported questions on attendance, and Panel B reports results on enrollment. None of the treatments generates statistically significant improvements relative to the control group. ${ }^{33}$

Last we examine several attitudinal indices, and child labor, in Table 7. Starting with the five attitudinal indexes, we note caution in interpretation: in theory, these may be either intermediate outcomes influenced directly by the treatment(s), or consequences of the shift in resources and test scores. In practice, we observe only two statistically significant shifts out of 20 estimates. ${ }^{34}$

In terms of child labor, critics of financial education for youth posit that introducing children to savings and financial decision-making may have the unintended consequence of focusing their attention on income, and then discourage school attendance in order to work (Varcoe et al. 2005). Berry, Karlan and Pradhan (2018) tests this in Ghana with students of similar age as this study, and finds that a financial education curriculum along with a savings box (but no directive or facilitation of using the savings for education expenses) did lead to higher child labor, whereas if a social values component was added to the financial education curriculum, there was no impact on child labor. In our setting, we find no impact from the program on child labor, either hours worked or total wages. Overall, the estimates from Tables 6 and 7, combined with the other outcomes, indicate that the observed effects on learning occur through changes in available supplies rather than changes in attitude or participation.

${ }^{33}$ Appendix Table 4d presents the results for the components of the index.

${ }^{34}$ Appendix Tables $4 \mathrm{e}-4 \mathrm{f}$ present the results for the components of these indices. 
Although we could examine whether individuals who saved more also experienced higher increases in test scores, we have no instrument for saving more beyond the experimental variation, and thus are unable to explore such a specification without ignoring endogeneity issues (i.e., that individuals who save more are also investing more in other ways to their education). Thus we do not explore such heterogeneity as part of our robustness tests.

To explore econometric robustness and robustness to risks of baseline imbalance, Appendix Tables 5 and 6 present the core results (Tables 4 to 5), except with covariates for all baseline values of outcome variables. We find no changes in the core results.

\section{Conclusion}

Weaker rather than stronger commitments can yield stronger impacts on behavior change. Specifically, in the context of an educational savings program, we find that families and children save more under a weaker commitment than a stricter commitment. The key difference was whether the funds had to be spent on educational expenses (strict) or were merely intended for the same (weak).

The purpose of commitment savings devices is to intentionally limit the use of deposited funds. In some contexts, however, such services may need to strike a balance between providing sufficient limitations to make the savings mechanisms useful while being careful not to make the limitations so severe that they deter savings. The stricter limitations may work worse for behavioral reasons (e.g., wanting option value or judgment to change own's mind) or for institutional reasons (e.g., not trusting the institution that is offering the commitment device). In our setup, for example, the voucher (i.e., stricter) treatment may work worse because individuals do not trust that proper and fairly priced school supplies will be available. However, although this seems plausible in the first year, we believe by the second year, after seeing the program work for a year, households should have learned that the right school supplies would be available at a reasonable price. Understanding the nature of this trade-off between strict and loose commitment is an important direction for future research.

When combined with a parent sensitization program, we find that families and children in the cash arm spend their savings on educational expenses (school supplies). ${ }^{35}$ This does not, however, alter school participation - we find no effects on enrollment or attendance - but does improve students' scores on grammar by 0.13 standard deviations and on reading by 0.11 standard deviations (and on aggregate test scores, include math, by 0.10 standard deviations). This suggests that financial constraints may play an important role in students' academic performance and that understanding

\footnotetext{
${ }^{35}$ Although we find that the voucher treatment led to about half the deposits as that of the cash arm, we do not find that school supplies increased by half. We posit two possible explanations. First, although the point estimate is close to zero, we cannot reject, statistically, a point estimate of half of that of the cash treatment effect. Second, the voucher treatment arm may have led to a reduction in school supplies through an anchoring effect (if the amount saved in vouchers was smaller for some than they would have spent otherwise).
} 
the role of families' financial decision process may be an important element in understanding the overall production process of education.

On a practical level, we consider several implementation issues important to explore. As a program designed to improve student learning, treatment effects of this magnitude are large compared to other evaluations of interventions designed to provide resources to schools or directly to children (Jameel Poverty Action Lab 2014), but they are small relative to many other types of programs (most notably, for example, programs that provide additional resources while also changing pedagogical strategies). Taking the programs relatively low cost (2.24 USD per student per year) into account using the methodology proposed by Dhaliwal et. al. (2014), however, the program delivers learning gains at a cost of 1.49 USD per tenth of a standard deviation or 6.71 standard deviations per $100 \mathrm{USD}^{36}$ (note our estimates ignore the opportunity cost to the family of the alternative use of the funds saved). This is very competitive relative to other programs. Relative to the 27 studies compared by J-PAL (2014), only four produce improvements in test scores more cost-effectively.

In terms of encouraging family savings, the program costs were high relative to the savings generated. However, if the program generated long term savings behavior change, then between the continued savings and the improvement in educational outcomes, it would surpass typical cost benefit calculations. Because we do not observe changes in attitudes, however, we cannot confidently predict that the long-term impacts will sustain themselves (although lack of attitude changes does not mean the results will not sustain themselves: attitudes are difficult to measure and may merely reflect noise, and furthermore the habit and pattern of saving could change and sustain without changing attitudes (e.g., see Horn et al. 2022)). On the cost side, it may be possible to reduce costs, particularly with implementation via mobile banking. This would obviate the need for physical transfer of cash to a bank and lower the risk of theft from keeping cash in a (albeit locked) box at the school. However, if the group nature of the intervention (i.e., the public and communal training) was an important element for take-up (through mimicking of or learning from peers) and adherence (through monitoring and potential for social recognition), then a mobile banking implementation may lose that visual classroom element. Although these peer mechanisms were not emphasized in the training and implementation of the program, the fact that the savings were done publicly may have had such an effect.

On a more theoretical level, these results open up many related questions. How does the optimality of looser versus stricter commitments depend on whether savings is long term or short-term? If one is saving for potentially short-run needs, such as a buffer stock, looser knots may be optimal; whereas long-term savings, such as for retirement, may require tighter commitments as the benefits from savings are too remote. Also with respect to timing, are external interventions of this sort

\footnotetext{
${ }^{36}$ Estimates are provided in 2011 USD.
} 
effective in changing long term behavior, i.e., does the psychic cost of deviation persist, even without an outsider-led intervention?

Questions also persist regarding how such interventions influence intra-household dynamics. Did the intervention shift the preferences of the child, or the parents, or both, and what does this imply for intra-household cross-generational bargaining issues?

Lastly, design issues may be critical for such a program to work. For example, how critical was the timing element of the "soft" commitment device, i.e., the fact that the school supplies were immediately available for purchase at the time of withdrawal? If that was critical, it is a ringing endorsement for the "make it easy" mantra, and also implies that the soft commitment device may have worked for reasons elaborated on in Mullainathan and Shafir (2013), because it increased the attention of individuals to educational expenses at exactly the right moment, when they had cash in their hands. 
Figure 1: Research Timeline

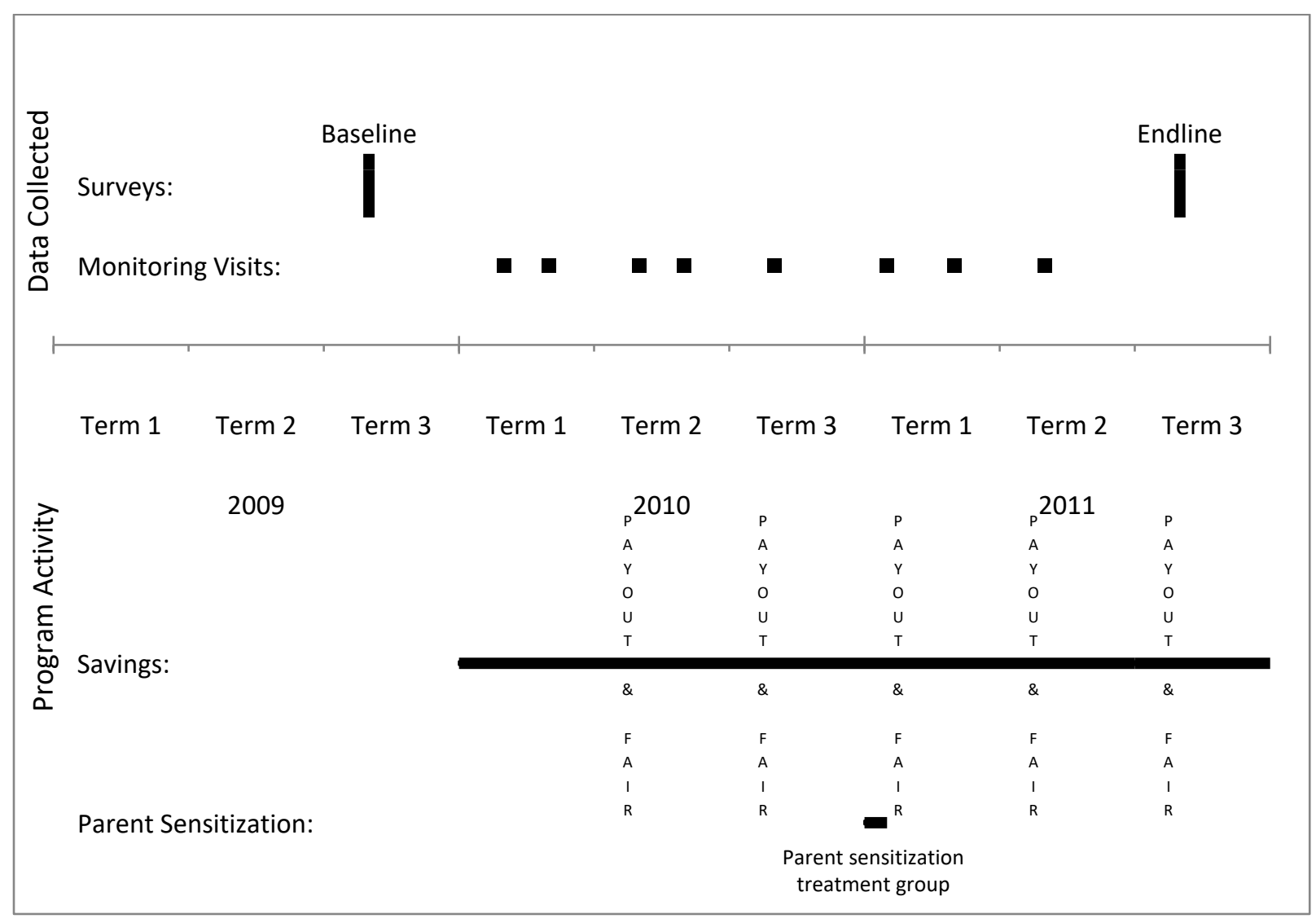




\section{References}

Amador, Manuel, Iván Werning, and George-Marios Angeletos. 2006. "Commitment vs. Flexibility." Econometrica 74 (2): 365-96. https://doi.org/10.1111/j.1468-0262.2006.00666.x.

Ashraf, Nava, Dean Karlan, and Wesley Yin. 2006. "Tying Odysseus to the Mast: Evidence From a Commitment Savings Product in the Philippines." The Quarterly Journal of Economics 121 (2): 635-72. https://doi.org/10.1162/qjec.2006.121.2.635.

- - . 2010. "Female Empowerment: Further Evidence from a Commitment Savings Product in the Philippines." World Development 38 (3): 333-44.

Avvisati, Francesco, Marc Gurgand, Nina Guyon, and Eric Maurin. 2013. "Getting Parents Involved: A Field Experiment in Deprived Schools." The Review of Economic Studies, August, rdt027. https://doi.org/10.1093/restud/rdt027.

Barrera-Osorio, Felipe, Marianne Bertrand, Leigh Linden, and Francisco Perez-Calle. 2011. "Improving the Design of Conditional Transfer Programs: Evidence from a Randomized Education Experiment in Colombia." American Economic Journal: Applied Economics 3 (2): 167-95.

Benabou, Roland, and Jean Tirole. 2004. "Willpower and Personal Rules." Journal of Political Economy 112 (4): 848-87.

Berry, James, Dean Karlan, and Menno Pradhan. 2018. "The Impact of Financial Education for Youth in Ghana." World Development 102 (February): 71-89. https://doi.org/10.1016/j.worlddev.2017.09.011.

Beshears, John, James J. Choi, Christopher Harris, David Laibson, Brigitte C. Madrian, and Jung Sakong. 2017. "Which Early Withdrawal Penalty Attracts the Most Deposits to a Commitment Savings Account?" Working Paper.

Brune, Lasse, Xavier Giné, Jessica Goldberg, and Dean Yang. 2016. "Facilitating Savings for Agriculture: Field Experimental Evidence from Malawi." Economic Development and Cultural Change 64 (2): 187-220. https://doi.org/10.1086/684014.

Burke, Jeremy, Jill Luoto, and Francisco Perez-Arce. 2017. "Soft versus Hard Commitments: A Test on Savings Behaviors." Journal of Consumer Affairs, November, n/a-n/a. https://doi.org/10.1111/joca.12170.

Clement, Douglas. 2013. "Interview with Richard Thaler." The Region, September 2013.

Das, Jishnu, Stefan Dercon, James Habyarimana, Pramila Krishnan, Karthik Muralidharan, and Venkatesh Sundararaman. 2013. "School Inputs, Household Substitution, and Teset Scores." American Economic Journal: Applied Economics 5 (2): 29-57.

De Arcangelis, Giuseppe, Majlinda Joxhe, David McKenzie, Erwin Tiongson, and Dean Yang. 2014. "Directing Remittances to Education with Soft and Hard Commitments: Evidence from a Lab-inthe-Field Experiment and New Product Take-up among Filipino Migrants in Rome." The World Bank: Policy Research Working Paper, May.

Dhaliwal, lqbal, Esther Duflo, Rachel Glennerster, and Caitlin Tulloch. 2014. "Comparative CostEffectiveness to Inform Policy in Developing Countries." In Education Policy in Developing Countries, edited by Paul Glewwe. Chicago, IL: University of Chicago Press.

Duflo, Esther, Michael Kremer, and Jonathan Robinson. 2011. "Nudging Farmers to Use Fertilizer: Theory and Experimental Evidence from Kenya." American Economic Review 101 (6): 2350-90. https://doi.org/10.1257/aer.101.6.2350.

Dupas, Pascaline, and Jonathan Robinson. 2013. "Why Don't the Poor Save More? Evidence from Health Savings Experiments." American Economic Review 103 (4): 1138-71. https://doi.org/10.1257/aer.103.4.1138.

Giné, Xavier, Jessica Goldberg, Dan Silverman, and Dean Yang. 2018. "Revising Commitments: Field Evidence on the Adjustment of Prior Choices." The Economic Journal 128 (608): 159-88. 
Hidalgo, Diana, Mercedes Onofa, Hessel Oosterbeek, and Juan Ponce. 2013. "Can Provision of Free School Uniforms Harm Attendance? Evidence from Ecuador." Journal of Development Economics 103: 43-51.

Horn, Samantha, Julian Jamison, Dean Karlan, and Jonathan Zinman. 2022. "Five-Year Impacts of GroupBased Financial Education and Savings Promotion for Ugandan Youth." Northwestern University Global Poverty Research Lab Working Paper.

Independent Evaluation Group (IEG). 2007. "Fall out from the 'Big Bang' Approach to Universal Primary Education: The Case of Uganda." World Bank. http://www.worldbank.org/oed/education/uganda.html.

Jameel Poverty Action Lab. 2014. "Student Learning." M.I.T. http://www.povertyactionlab.org/policylessons/education/student-learning.

John, Anett. 2020. "When Commitment Fails: Evidence from a Field Experiment." Management Science 66 (2): 503-29. https://doi.org/10.1287/mnsc.2018.3236.

Karlan, Dean, Margaret McConnell, Sendhil Mullainathan, and Jonathan Zinman. 2016. "Getting to the Top of Mind: How Reminders Increase Saving." Management Science 62 (12): 3393-3411.

Karlan, Dean, Aishwarya Lakshmi Ratan, and Jonathan Zinman. 2014. "Savings by and for the Poor: A Research Review and Agenda." Review of Income and Wealth 60 (1): 36-78. https://doi.org/10.1111/roiw.12101.

Kremer, Michael, and Alaka Holla. 2009. "Pricing and Access: Lessons from Randomized Evaluations in Education and Health." In What Works in Development? Thinking Big and Thinking Small, edited by Jessica Cohen and William Easterly. Brookings Institution Press.

Mullainathan, Sendhil, and Eldar Shafir. 2013. Scarcity: Why Having Too Little Means so Much. New York: Times Books, Henry Holt and Company.

Murphy, Paul, Carla Bertoncino, and Lianqin Wang. 2002. "Achieving Universal Primary Education in Uganda: The 'Big Bang' Approach.” 24107. Education Notes. Washington, D.C.: The World Bank. http://documents.worldbank.org/curated/en/2002/04/12947917/achieving-universal-primaryeducation-uganda-big-bang-approach.

"Opportunities Lost: The Impact of Grade Repetition and Early School Leaving." 2012. Global Education Digest 2012. UNESCO Institute for Statistics.

Piper, Benjamin. 2010. "Uganda Early Grade Reading Assessment Findings Report: Literacy Aquisition and Mother Tongue." Makerere Institute for Social Research.

Shefrin, H., and R. Thaler. 1992. "Mental Accounting, Saving, and Self-Control." In Choice Over Time. New York: Russell Sage Foundation.

Thaler, Richard H, and Cass R Sunstein. 2009. Nudge: Improving Decisions about Health, Wealth, and Happiness. New York: Penguin Books.

UN data. 2013. "Uganda." United National Statistical Division. http://data.un.org/CountryProfile.aspx?crName=Uganda.

UNESCO. 2013. "Data Centre." Institute for Statistics. 2013. http://www.uis.unesco.org/Pages/DataCentre.aspx.

Varcoe, Karen P., Allen Martin, Zana Devitto, and Charles Go. 2005. "Using a Financial Education Curriculum for Teens." Journal of Financial Counseling and Planning 16 (1): 63-71. 
Table 1: Summary Statistics and Orthogonality Verification of Random Assignment, Full Sample Frame from Baseline Mean (standard deviation) and OLS

\begin{tabular}{|c|c|c|c|c|c|c|c|c|c|}
\hline \multirow[b]{2}{*}{ Dependent Variables } & \multirow{2}{*}{$\begin{array}{l}\text { Number } \\
\text { of Obs. } \\
\text { (1) }\end{array}$} & $\begin{array}{r}\mathrm{Me} \\
\text { (std d }\end{array}$ & & \multirow{2}{*}{$\begin{array}{c}\text { OLS (one } \\
\text { specification } \\
\text { per cell) } \\
\text { Any } \\
\text { Treatment } \\
(4) \\
\end{array}$} & \multicolumn{4}{|c|}{ OLS (one specification per row) } & \multirow{2}{*}{$\begin{array}{c}\text { P-value } \\
\text { for test of } \\
\text { Cash } \\
\text { Parent = } \\
\text { Other } \\
\text { Treatment } \\
\text { (9) }\end{array}$} \\
\hline & & $\begin{array}{c}\text { Any } \\
\text { Treatment } \\
\text { (2) }\end{array}$ & $\begin{array}{l}\text { Control } \\
\text { (3) }\end{array}$ & & $\begin{array}{l}\text { Cash with } \\
\text { Parent } \\
\text { Outreach } \\
\text { (5) }\end{array}$ & $\begin{array}{c}\text { Voucher } \\
\text { with Parent } \\
\text { Outreach } \\
\text { (6) }\end{array}$ & $\begin{array}{l}\text { Cash w/o } \\
\text { Parent } \\
\text { Outreach } \\
\text { (7) }\end{array}$ & $\begin{array}{l}\text { Voucher } \\
\text { w/o Parent } \\
\text { Outreach } \\
\text { (8) }\end{array}$ & \\
\hline Classroom Survey: \% of students in attendance & 811 & $\begin{array}{c}0.09 \\
(0.14)\end{array}$ & $\begin{array}{c}0.10 \\
(0.15)\end{array}$ & $\begin{array}{c}-0.01 \\
(0.01)\end{array}$ & $\begin{array}{l}-0.02 \\
(0.01)\end{array}$ & $\begin{array}{l}-0.01 \\
(0.01)\end{array}$ & $\begin{array}{l}-0.01 \\
(0.01)\end{array}$ & $\begin{array}{l}-0.01 \\
(0.01)\end{array}$ & 0.55 \\
\hline Classroom Survey: Supplies Index & 813 & $\begin{array}{c}0.03 \\
(2.06)\end{array}$ & $\begin{array}{c}0.01 \\
(2.05)\end{array}$ & $\begin{array}{c}0.02 \\
(0.10)\end{array}$ & $\begin{array}{l}0.22 * \\
(0.11)\end{array}$ & $\begin{array}{c}0.04 \\
(0.15)\end{array}$ & $\begin{array}{l}-0.12 \\
(0.19)\end{array}$ & $\begin{array}{l}-0.05 \\
(0.14)\end{array}$ & 0.02 \\
\hline Normalized Test Score: Grammar & 4710 & $\begin{array}{c}0.08 \\
(3.68)\end{array}$ & $\begin{array}{l}-0.00 \\
(3.82)\end{array}$ & $\begin{array}{c}0.11 \\
(0.07)\end{array}$ & $\begin{array}{c}0.12 \\
(0.11)\end{array}$ & $\begin{array}{l}-0.02 \\
(0.09)\end{array}$ & $\begin{array}{l}0.18 * \\
(0.10)\end{array}$ & $\begin{array}{c}0.14 \\
(0.09)\end{array}$ & 0.87 \\
\hline Normalized Test Score: Reading & 4713 & $\begin{array}{l}-0.00 \\
(3.74)\end{array}$ & $\begin{array}{l}-0.00 \\
(3.54)\end{array}$ & $\begin{array}{c}0.01 \\
(0.07)\end{array}$ & $\begin{array}{l}-0.02 \\
(0.10)\end{array}$ & $\begin{array}{l}-0.00 \\
(0.09)\end{array}$ & $\begin{array}{c}0.02 \\
(0.09)\end{array}$ & $\begin{array}{c}0.05 \\
(0.11)\end{array}$ & 0.59 \\
\hline Normalized Test Score: Math & 4715 & $\begin{array}{c}0.00 \\
(2.73)\end{array}$ & $\begin{array}{l}-0.00 \\
(2.81)\end{array}$ & $\begin{array}{c}0.02 \\
(0.06)\end{array}$ & $\begin{array}{l}-0.01 \\
(0.09)\end{array}$ & $\begin{array}{l}-0.07 \\
(0.08)\end{array}$ & $\begin{array}{c}0.07 \\
(0.10)\end{array}$ & $\begin{array}{c}0.08 \\
(0.10)\end{array}$ & 0.72 \\
\hline Normalized Test Score: Total & 4716 & $\begin{array}{c}0.03 \\
(3.82)\end{array}$ & $\begin{array}{l}-0.00 \\
(3.76)\end{array}$ & $\begin{array}{c}0.06 \\
(0.07)\end{array}$ & $\begin{array}{c}0.04 \\
(0.11)\end{array}$ & $\begin{array}{l}-0.03 \\
(0.09)\end{array}$ & $\begin{array}{c}0.11 \\
(0.10)\end{array}$ & $\begin{array}{c}0.11 \\
(0.11)\end{array}$ & 0.77 \\
\hline Student Survey: Attendance Code (lower = more attendance) & 4716 & $\begin{array}{c}1.43 \\
(2.81)\end{array}$ & $\begin{array}{c}1.42 \\
(2.47)\end{array}$ & $\begin{array}{c}0.00 \\
(0.07)\end{array}$ & $\begin{array}{l}-0.07 \\
(0.12)\end{array}$ & $\begin{array}{c}0.10 \\
(0.12)\end{array}$ & $\begin{array}{l}-0.01 \\
(0.11)\end{array}$ & $\begin{array}{c}0.00 \\
(0.10)\end{array}$ & 0.33 \\
\hline Student Survey: Days missed per school term & 3886 & $\begin{array}{c}1.63 \\
(1.50)\end{array}$ & $\begin{array}{c}1.64 \\
(1.31)\end{array}$ & $\begin{array}{l}-0.02 \\
(0.04)\end{array}$ & $\begin{array}{l}-0.04 \\
(0.07)\end{array}$ & $\begin{array}{l}-0.06 \\
(0.07)\end{array}$ & $\begin{array}{l}-0.07 \\
(0.07)\end{array}$ & $\begin{array}{l}0.10^{*} \\
(0.06)\end{array}$ & 0.57 \\
\hline Student Survey: Prefer 500 UGX today to 800 UGX tomorrow & 4702 & $\begin{array}{c}0.65 \\
(0.92)\end{array}$ & $\begin{array}{c}0.64 \\
(0.72)\end{array}$ & $\begin{array}{c}0.01 \\
(0.02)\end{array}$ & $\begin{array}{c}0.02 \\
(0.04)\end{array}$ & $\begin{array}{l}-0.00 \\
(0.03)\end{array}$ & $\begin{array}{l}-0.04 \\
(0.03)\end{array}$ & $\begin{array}{c}0.07 * * \\
(0.03)\end{array}$ & 0.83 \\
\hline Student Survey: Prefer 500 UGX today to 800 UGX next week & 4699 & $\begin{array}{c}0.29 \\
(0.78)\end{array}$ & $\begin{array}{c}0.24 \\
(0.72)\end{array}$ & $\begin{array}{c}0.04 * * \\
(0.02)\end{array}$ & $\begin{array}{c}0.06 \\
(0.04)\end{array}$ & $\begin{array}{c}0.07 * * \\
(0.03)\end{array}$ & $\begin{array}{l}-0.02 \\
(0.03)\end{array}$ & $\begin{array}{c}0.07 * * \\
(0.03)\end{array}$ & 0.68 \\
\hline Student Survey: Child receives pocket money from family & 4678 & $\begin{array}{c}0.75 \\
(0.65)\end{array}$ & $\begin{array}{c}0.74 \\
(0.62)\end{array}$ & $\begin{array}{c}0.01 \\
(0.02)\end{array}$ & $\begin{array}{c}-0.02 \\
(0.02)\end{array}$ & $\begin{array}{c}0.03 \\
(0.03)\end{array}$ & $\begin{array}{c}0.07 * * * \\
(0.02)\end{array}$ & $\begin{array}{l}-0.02 \\
(0.03)\end{array}$ & 0.04 \\
\hline Student Survey: Amount received in pocket money (UGX) & 4698 & $\begin{array}{c}204.20 \\
(443.72)\end{array}$ & $\begin{array}{c}214.45 \\
(554.53)\end{array}$ & $\begin{array}{c}-7.92 \\
(13.91)\end{array}$ & $\begin{array}{l}-17.84 \\
(16.31)\end{array}$ & $\begin{array}{c}-1.30 \\
(19.61)\end{array}$ & $\begin{array}{c}9.69 \\
(18.07)\end{array}$ & $\begin{array}{l}-21.83 \\
(19.39)\end{array}$ & 0.30 \\
\hline Student Survey: Primary use of money earned is school supplies & 1983 & $\begin{array}{c}0.23 \\
(0.53)\end{array}$ & $\begin{array}{c}0.27 \\
(0.55)\end{array}$ & $\begin{array}{c}-0.04 \\
(0.02)\end{array}$ & $\begin{array}{c}-0.03 \\
(0.03)\end{array}$ & $\begin{array}{c}-0.02 \\
(0.04)\end{array}$ & $\begin{array}{c}-0.07^{* *} \\
(0.03)\end{array}$ & $\begin{array}{c}-0.03 \\
(0.04)\end{array}$ & 0.89 \\
\hline $\begin{array}{l}\text { Joint Significance Test F-stat, one regression per column with } \\
\text { column header as dep var (p-value) }\end{array}$ & & & & $\begin{array}{c}1.35 \\
(0.21)\end{array}$ & $\begin{array}{c}1.16 \\
(0.32)\end{array}$ & $\begin{array}{c}1.08 \\
(0.38)\end{array}$ & $\begin{array}{c}1.25 \\
(0.27)\end{array}$ & $\begin{array}{l}1.10 \\
(0.37)\end{array}$ & \\
\hline
\end{tabular}

\% of students in attendance: The entme

$\%$ of students in attendance: The enumerators count of the number of students present during a classroom visit, divided by the enrollment in the class as provided by the teacher. Supplies

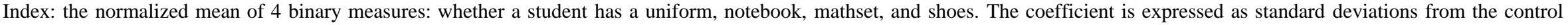

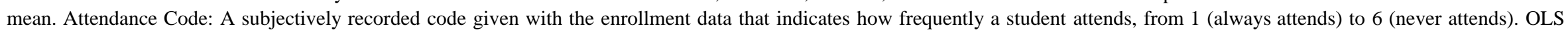

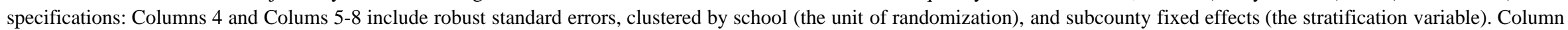

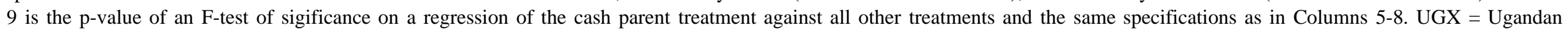
Shillings, 1 USD $=2815$ UGX. * $\mathrm{p}<0.10 * * \mathrm{p}<0.05 * * * \mathrm{p}<0.01$ 
Table 2: Summary Statistics and Orthogonality Verification of Random Assignment, Post-Attrition Sample Frame

Mean (standard deviation) and OLS

\begin{tabular}{|c|c|c|c|c|c|c|c|c|c|}
\hline \multirow[b]{2}{*}{ Dependent Variables } & \multirow{2}{*}{$\begin{array}{l}\text { Number } \\
\text { of Obs. } \\
\text { (1) }\end{array}$} & \multicolumn{2}{|c|}{$\begin{array}{c}\text { Mean } \\
\text { (std dev) }\end{array}$} & \multirow{2}{*}{$\begin{array}{c}\text { OLS (one } \\
\text { specification } \\
\text { per cell) } \\
\text { Any } \\
\text { Treatment } \\
\text { (4) }\end{array}$} & \multicolumn{4}{|c|}{ OLS (one specification per row) } & \multirow{2}{*}{$\begin{array}{l}\text { P-value for } \\
\text { test of } \\
\text { Cash } \\
\text { Parent = } \\
\text { Other } \\
\text { Treatments } \\
\text { (9) }\end{array}$} \\
\hline & & $\begin{array}{c}\text { Any } \\
\text { Treatment } \\
\text { (2) }\end{array}$ & $\begin{array}{l}\text { Control } \\
\text { (3) }\end{array}$ & & $\begin{array}{l}\text { Cash with } \\
\text { Parent } \\
\text { Outreach } \\
\text { (5) }\end{array}$ & $\begin{array}{c}\text { Voucher } \\
\text { with Parent } \\
\text { Outreach } \\
\text { (6) }\end{array}$ & $\begin{array}{l}\text { Cash w/o } \\
\text { Parent } \\
\text { Outreach } \\
\text { (7) }\end{array}$ & $\begin{array}{c}\text { Voucher w/o } \\
\text { Parent } \\
\text { Outreach } \\
\text { (8) }\end{array}$ & \\
\hline Endline survey completed (of baseline students) & 4716 & $\begin{array}{c}0.82 \\
(0.39)\end{array}$ & $\begin{array}{c}0.81 \\
(0.39)\end{array}$ & $\begin{array}{c}0.00 \\
(0.01)\end{array}$ & $\begin{array}{c}0.01 \\
(0.02)\end{array}$ & $\begin{array}{c}0.00 \\
(0.02)\end{array}$ & $\begin{array}{c}-0.01 \\
(0.02)\end{array}$ & $\begin{array}{c}0.02 \\
(0.02)\end{array}$ & 0.74 \\
\hline Normalized Test Score: Grammar & 3832 & $\begin{array}{c}0.09 \\
(3.35)\end{array}$ & $\begin{array}{c}0.01 \\
(3.46)\end{array}$ & $\begin{array}{c}0.11 \\
(0.07)\end{array}$ & $\begin{array}{c}0.13 \\
(0.11)\end{array}$ & $\begin{array}{l}-0.02 \\
(0.09)\end{array}$ & $\begin{array}{c}0.19 * * \\
(0.09)\end{array}$ & $\begin{array}{c}0.14 \\
(0.10)\end{array}$ & 0.81 \\
\hline Normalized Test Score: Reading & 3835 & $\begin{array}{c}0.01 \\
(3.37)\end{array}$ & $\begin{array}{c}0.01 \\
(3.18)\end{array}$ & $\begin{array}{c}0.02 \\
(0.07)\end{array}$ & $\begin{array}{l}-0.00 \\
(0.11)\end{array}$ & $\begin{array}{c}0.01 \\
(0.09)\end{array}$ & $\begin{array}{c}0.02 \\
(0.09)\end{array}$ & $\begin{array}{c}0.06 \\
(0.12)\end{array}$ & 0.66 \\
\hline Normalized Test Score: Math & 3837 & $\begin{array}{l}-0.00 \\
(2.50)\end{array}$ & $\begin{array}{c}0.01 \\
(2.55)\end{array}$ & $\begin{array}{c}0.02 \\
(0.06)\end{array}$ & $\begin{array}{c}0.01 \\
(0.09)\end{array}$ & $\begin{array}{l}-0.07 \\
(0.09)\end{array}$ & $\begin{array}{c}0.05 \\
(0.10)\end{array}$ & $\begin{array}{c}0.07 \\
(0.10)\end{array}$ & 0.85 \\
\hline Normalized Test Score: Total & 3837 & $\begin{array}{c}0.04 \\
(3.44)\end{array}$ & $\begin{array}{c}0.01 \\
(3.36)\end{array}$ & $\begin{array}{c}0.06 \\
(0.07)\end{array}$ & $\begin{array}{c}0.06 \\
(0.11)\end{array}$ & $\begin{array}{l}-0.02 \\
(0.09)\end{array}$ & $\begin{array}{c}0.10 \\
(0.09)\end{array}$ & $\begin{array}{c}0.10 \\
(0.11)\end{array}$ & 0.87 \\
\hline Student Survey: Attendance Code (lower = more attendance) & 3837 & $\begin{array}{c}1.42 \\
(2.53)\end{array}$ & $\begin{array}{c}1.42 \\
(2.14)\end{array}$ & $\begin{array}{l}-0.02 \\
(0.07)\end{array}$ & $\begin{array}{l}-0.08 \\
(0.12)\end{array}$ & $\begin{array}{c}0.07 \\
(0.12)\end{array}$ & $\begin{array}{l}-0.04 \\
(0.10)\end{array}$ & $\begin{array}{l}-0.02 \\
(0.10)\end{array}$ & 0.39 \\
\hline Student Survey: Days missed per school term & 3145 & $\begin{array}{c}1.62 \\
(1.42)\end{array}$ & $\begin{array}{c}1.63 \\
(1.19)\end{array}$ & $\begin{array}{l}-0.01 \\
(0.05)\end{array}$ & $\begin{array}{l}-0.03 \\
(0.07)\end{array}$ & $\begin{array}{l}-0.04 \\
(0.08)\end{array}$ & $\begin{array}{l}-0.06 \\
(0.07)\end{array}$ & $\begin{array}{c}0.08 \\
(0.06)\end{array}$ & 0.56 \\
\hline Student Survey: Prefer 500 UGX today to 800 UGX next week & 3824 & $\begin{array}{c}0.65 \\
(0.84)\end{array}$ & $\begin{array}{c}0.65 \\
(0.67)\end{array}$ & $\begin{array}{c}0.00 \\
(0.02)\end{array}$ & $\begin{array}{c}0.01 \\
(0.04)\end{array}$ & $\begin{array}{c}0.00 \\
(0.04)\end{array}$ & $\begin{array}{l}-0.06^{*} \\
(0.03)\end{array}$ & $\begin{array}{c}0.06 \\
(0.04)\end{array}$ & 0.92 \\
\hline Student Survey: Prefer 500 UGX today to 1,000 UGX next week & 3821 & $\begin{array}{c}0.29 \\
(0.72)\end{array}$ & $\begin{array}{c}0.25 \\
(0.69)\end{array}$ & $\begin{array}{l}0.04 * \\
(0.02)\end{array}$ & $\begin{array}{c}0.05 \\
(0.04)\end{array}$ & $\begin{array}{l}0.06 * \\
(0.03)\end{array}$ & $\begin{array}{l}-0.01 \\
(0.03)\end{array}$ & $\begin{array}{l}0.06^{*} \\
(0.03)\end{array}$ & 0.67 \\
\hline Student Survey: Child receives pocket money from family & 3805 & $\begin{array}{c}0.75 \\
(0.62)\end{array}$ & $\begin{array}{c}0.74 \\
(0.62)\end{array}$ & $\begin{array}{c}0.01 \\
(0.02)\end{array}$ & $\begin{array}{c}-0.01 \\
(0.02)\end{array}$ & $\begin{array}{c}0.02 \\
(0.03)\end{array}$ & $\begin{array}{c}0.06^{* *} \\
(0.02)\end{array}$ & $\begin{array}{c}-0.02 \\
(0.03)\end{array}$ & 0.19 \\
\hline Student Survey: Amount received in pocket money (UGX) & 3821 & $\begin{array}{c}199.30 \\
(388.68)\end{array}$ & $\begin{array}{c}217.59 \\
(585.52)\end{array}$ & $\begin{array}{l}-15.15 \\
(15.12)\end{array}$ & $\begin{array}{c}-18.53 \\
(18.68)\end{array}$ & $\begin{array}{l}-12.75 \\
(21.49)\end{array}$ & $\begin{array}{c}5.05 \\
(18.94)\end{array}$ & $\begin{array}{l}-32.81^{*} \\
(17.66)\end{array}$ & 0.66 \\
\hline Student Survey: Primary use of money earned is school supplies & 1647 & $\begin{array}{c}0.22 \\
(0.49)\end{array}$ & $\begin{array}{c}0.26 \\
(0.51)\end{array}$ & $\begin{array}{l}-0.04 \\
(0.02)\end{array}$ & $\begin{array}{l}-0.03 \\
(0.03)\end{array}$ & $\begin{array}{l}-0.02 \\
(0.04)\end{array}$ & $\begin{array}{c}-0.08 * * * \\
(0.03)\end{array}$ & $\begin{array}{l}-0.02 \\
(0.04)\end{array}$ & 0.77 \\
\hline
\end{tabular}

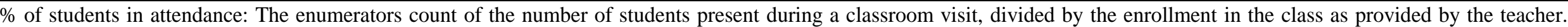

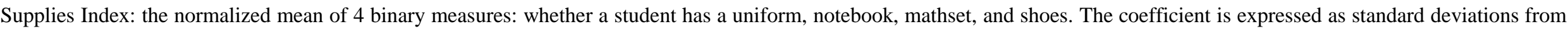

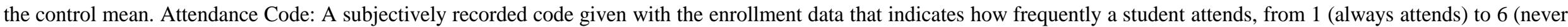

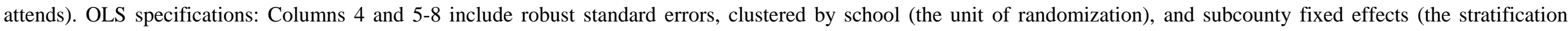

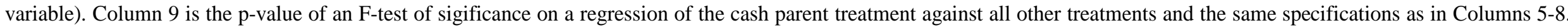
UGX $=$ Ugandan Shillings, 1 USD $=2815$ UGX. * $\mathrm{p}<0.10 * * \mathrm{p}<0.05 * * * \mathrm{p}<0.01$ 
Table 3: Super Savers Program Savings by Treatment Group in '000 UGX

Mean (standard deviation)

\begin{tabular}{|c|c|c|c|c|c|c|}
\hline & \multicolumn{4}{|c|}{$\begin{array}{c}\text { Mean } \\
\text { (standard deviation) }\end{array}$} & \multicolumn{2}{|c|}{ P-value from t-test } \\
\hline & $\begin{array}{c}\text { Cash } \\
\text { with } \\
\text { Parent } \\
\text { Outreach } \\
\text { (1) }\end{array}$ & $\begin{array}{c}\text { Cash } \\
\text { w/o } \\
\text { Parent } \\
\text { Outreach } \\
(2) \\
\end{array}$ & $\begin{array}{l}\text { Voucher } \\
\text { with } \\
\text { Parent } \\
\text { Outreach } \\
\text { (3) } \\
\end{array}$ & $\begin{array}{c}\text { Voucher } \\
\text { w/o } \\
\text { Parent } \\
\text { Outreach } \\
(4) \\
\end{array}$ & $\begin{array}{c}\text { Cash } \\
\text { vs. } \\
\text { Voucher } \\
\text { (5) }\end{array}$ & $\begin{array}{c}\text { Outreach } \\
\text { vs. } \\
\text { No Outreach } \\
(6)\end{array}$ \\
\hline \multicolumn{7}{|l|}{ Panel A: 2010} \\
\hline Average Cumulative Deposits Made per School (2010) & $\begin{array}{c}180.29 \\
(232.49)\end{array}$ & $\begin{array}{c}186.76 \\
(126.37)\end{array}$ & $\begin{array}{l}109.09 \\
(84.84)\end{array}$ & $\begin{array}{l}105.24 \\
(86.44)\end{array}$ & 0.02 & 0.95 \\
\hline Average Cumulative Deposits Made per Student in 2010 (any attendance) & $\begin{array}{c}0.95 \\
(0.84)\end{array}$ & $\begin{array}{c}0.99 \\
(0.73)\end{array}$ & $\begin{array}{c}0.58 \\
(0.52)\end{array}$ & $\begin{array}{c}0.48 \\
(0.39)\end{array}$ & 0.00 & 0.96 \\
\hline Average Cumulative Deposits Made per Student in 2010 (avg attendance) & $\begin{array}{c}1.28 \\
(1.08)\end{array}$ & $\begin{array}{c}1.43 \\
(1.11)\end{array}$ & $\begin{array}{c}0.78 \\
(0.67)\end{array}$ & $\begin{array}{c}0.69 \\
(0.60)\end{array}$ & 0.00 & 0.83 \\
\hline \multicolumn{7}{|l|}{ Panel B: 2011} \\
\hline Average Cumulative Deposits Made per School (2011) & $\begin{array}{c}346.78 \\
(357.38)\end{array}$ & $\begin{array}{c}366.47 \\
(225.81)\end{array}$ & $\begin{array}{c}156.78 \\
(71.03)\end{array}$ & $\begin{array}{c}185.07 \\
(128.67)\end{array}$ & 0.00 & 0.59 \\
\hline Average Cumulative Deposits Made per Student in 2011 (any attendance) & $\begin{array}{c}3.60 \\
(5.47)\end{array}$ & $\begin{array}{c}2.91 \\
(2.22)\end{array}$ & $\begin{array}{c}1.26 \\
(0.61)\end{array}$ & $\begin{array}{c}1.51 \\
(1.34)\end{array}$ & 0.03 & 0.73 \\
\hline Average Cumulative Deposits Made per Student in 2011 (avg attendance) & $\begin{array}{c}4.41 \\
(6.98)\end{array}$ & $\begin{array}{c}3.67 \\
(2.90)\end{array}$ & $\begin{array}{c}1.60 \\
(0.68)\end{array}$ & $\begin{array}{c}1.77 \\
(1.55)\end{array}$ & 0.03 & 0.71 \\
\hline Observations (Schools) & 19 & 20 & 19 & 20 & & \\
\hline
\end{tabular}

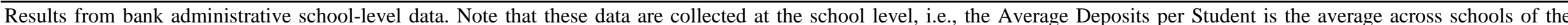

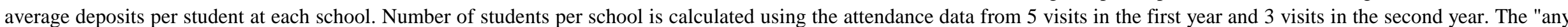

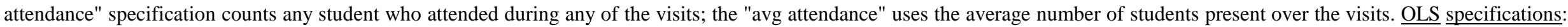
Columns 5-6 include subcounty fixed effects (the stratification variable). UGX $=$ Ugandan Shillings, 1 USD $=2815$ UGX. * $\mathrm{p}<0.10 * * \mathrm{p}<0.05 * * * \mathrm{p}<0.01$. 
Table 4: Process and Intermediate Outcomes, Intent to Treat Estimates Mean (standard deviation) and OLS

\begin{tabular}{|c|c|c|c|c|c|c|c|c|c|}
\hline \multirow[b]{2}{*}{ Dependent Variables } & \multirow{2}{*}{$\begin{array}{l}\text { Number } \\
\text { of Obs. } \\
\text { (1) }\end{array}$} & \multicolumn{2}{|c|}{$\begin{array}{c}\text { Mean } \\
\text { (std dev) }\end{array}$} & \multirow{2}{*}{$\begin{array}{c}\text { OLS (one } \\
\text { specification } \\
\text { per cell) } \\
\text { Any } \\
\text { Treatment } \\
\text { (4) }\end{array}$} & \multicolumn{4}{|c|}{$\begin{array}{c}\text { OLS } \\
(\text { each row }=\text { one regression })\end{array}$} & \multirow{2}{*}{$\begin{array}{l}\text { P-value for } \\
\text { test of Cash } \\
\text { Parent = } \\
\text { Other } \\
\text { Treatments } \\
\text { (9) }\end{array}$} \\
\hline & & $\begin{array}{c}\text { Any } \\
\text { Treatment } \\
(2)\end{array}$ & $\begin{array}{c}\text { Control } \\
\text { (3) }\end{array}$ & & $\begin{array}{l}\text { Cash with } \\
\text { Parent } \\
\text { Outreach } \\
\text { (5) }\end{array}$ & $\begin{array}{c}\text { Voucher } \\
\text { with Parent } \\
\text { Outreach } \\
\text { (6) }\end{array}$ & $\begin{array}{l}\text { Cash w/o } \\
\text { Parent } \\
\text { Outreach } \\
\text { (7) }\end{array}$ & $\begin{array}{l}\text { Voucher } \\
\text { w/o Parent } \\
\text { Outreach } \\
\text { (8) }\end{array}$ & \\
\hline \multicolumn{10}{|l|}{ Panel A: Process Outcomes (Endline Survey - 2011) } \\
\hline Heard of Super Savers program & 3823 & $\begin{array}{c}0.79 \\
(0.41)\end{array}$ & $\begin{array}{c}0.11 \\
(0.32)\end{array}$ & $\begin{array}{c}0.67 * * * \\
(0.02)\end{array}$ & $\begin{array}{c}0.69 * * * \\
(0.02)\end{array}$ & $\begin{array}{c}0.67^{* * *} \\
(0.03)\end{array}$ & $\begin{array}{c}0.68 * * * \\
(0.02)\end{array}$ & $\begin{array}{c}0.64 * * * \\
(0.03)\end{array}$ & 0.24 \\
\hline Ever Talked with Parent about Saving & 3821 & $\begin{array}{c}0.51 \\
(0.50)\end{array}$ & $\begin{array}{c}0.36 \\
(0.48)\end{array}$ & $\begin{array}{l}0.15^{* * *} \\
(0.02)\end{array}$ & $\begin{array}{l}0.15^{* * *} \\
(0.03)\end{array}$ & $\begin{array}{l}0.13^{* * *} \\
(0.03)\end{array}$ & $\begin{array}{c}0.17^{* * *} \\
(0.03)\end{array}$ & $\begin{array}{c}0.16^{* * *} \\
(0.03)\end{array}$ & 0.77 \\
\hline Saved with Super Savers & 3824 & $\begin{array}{c}0.44 \\
(0.50)\end{array}$ & $\begin{array}{c}0.03 \\
(0.18)\end{array}$ & $\begin{array}{l}0.40^{* * *} \\
(0.02)\end{array}$ & $\begin{array}{c}0.42^{* * *} \\
(0.02)\end{array}$ & $\begin{array}{c}0.39 * * * \\
(0.04)\end{array}$ & $\begin{array}{c}0.44 * * * \\
(0.03)\end{array}$ & $\begin{array}{c}0.35^{* * *} \\
(0.04)\end{array}$ & 0.41 \\
\hline Ever Saves Money & 3821 & $\begin{array}{c}0.79 \\
(0.40)\end{array}$ & $\begin{array}{c}0.79 \\
(0.41)\end{array}$ & $\begin{array}{c}0.01 \\
(0.02)\end{array}$ & $\begin{array}{c}0.01 \\
(0.02)\end{array}$ & $\begin{array}{c}0.02 \\
(0.03)\end{array}$ & $\begin{array}{c}0.02 \\
(0.03)\end{array}$ & $\begin{array}{l}-0.02 \\
(0.02)\end{array}$ & 0.87 \\
\hline Primary Source of Funds Saved was Work & 3830 & $\begin{array}{c}0.43 \\
(0.50)\end{array}$ & $\begin{array}{c}0.47 \\
(0.50)\end{array}$ & $\begin{array}{l}-0.03^{*} \\
(0.02)\end{array}$ & $\begin{array}{c}-0.06 * * \\
(0.03)\end{array}$ & $\begin{array}{l}-0.04 \\
(0.03)\end{array}$ & $\begin{array}{c}0.01 \\
(0.03)\end{array}$ & $\begin{array}{c}-0.04^{* *} \\
(0.02)\end{array}$ & 0.23 \\
\hline Any Funds Saved Came from Work & 3822 & $\begin{array}{c}0.49 \\
(0.50)\end{array}$ & $\begin{array}{c}0.53 \\
(0.50)\end{array}$ & $\begin{array}{l}-0.03^{*} \\
(0.02)\end{array}$ & $\begin{array}{c}-0.04 \\
(0.03)\end{array}$ & $\begin{array}{l}-0.04 \\
(0.03)\end{array}$ & $\begin{array}{c}0.00 \\
(0.03)\end{array}$ & $\begin{array}{c}-0.04^{* *} \\
(0.02)\end{array}$ & 0.71 \\
\hline Any Funds Saved Came from Other Sources & 3822 & $\begin{array}{c}0.50 \\
(0.50)\end{array}$ & $\begin{array}{c}0.47 \\
(0.50)\end{array}$ & $\begin{array}{c}0.03 \\
(0.02)\end{array}$ & $\begin{array}{c}0.04 \\
(0.03)\end{array}$ & $\begin{array}{c}0.04 \\
(0.03)\end{array}$ & $\begin{array}{c}0.02 \\
(0.03)\end{array}$ & $\begin{array}{c}0.02 \\
(0.02)\end{array}$ & 0.41 \\
\hline Number of locations actively used for saving & 3830 & $\begin{array}{c}0.86 \\
(0.61)\end{array}$ & $\begin{array}{c}0.79 \\
(0.52)\end{array}$ & $\begin{array}{c}0.08^{* * *} \\
(0.02)\end{array}$ & $\begin{array}{c}0.09 * * * \\
(0.03)\end{array}$ & $\begin{array}{l}0.10^{* *} \\
(0.04)\end{array}$ & $\begin{array}{l}0.07^{*} \\
(0.04)\end{array}$ & $\begin{array}{l}0.07^{* *} \\
(0.03)\end{array}$ & 0.71 \\
\hline In-school self-reported savings last term, wins. 95\% & 3830 & $\begin{array}{c}561 \\
(1168)\end{array}$ & $\begin{array}{c}63 \\
(438)\end{array}$ & $\begin{array}{c}493^{* * *} \\
(35)\end{array}$ & $\begin{array}{c}526 * * * \\
(58)\end{array}$ & $\begin{array}{c}416^{* * *} \\
(65)\end{array}$ & $\begin{array}{c}633^{* * *} \\
(70)\end{array}$ & $\begin{array}{c}405^{* * *} \\
(60)\end{array}$ & 0.51 \\
\hline Out-of-school self-reported savings last term, wins. 95\% & 3830 & $\begin{array}{c}4933 \\
(7956)\end{array}$ & $\begin{array}{c}6466 \\
(8290)\end{array}$ & $\begin{array}{c}-1392^{* * *} \\
(284)\end{array}$ & $\begin{array}{c}-1245^{* * *} \\
(472)\end{array}$ & $\begin{array}{c}-1728^{* * *} \\
(440)\end{array}$ & $\begin{array}{c}-1027^{* *} \\
(446)\end{array}$ & $\begin{array}{c}-1548^{* * *} \\
(380)\end{array}$ & 0.66 \\
\hline \multicolumn{10}{|l|}{ Panel B: Intermediate Outcomes (Classroom Visits) } \\
\hline School Supplies Index 2010 & 813 & $\begin{array}{c}-0.16 \\
(1.18)\end{array}$ & $\begin{array}{l}-0.10 \\
(0.89)\end{array}$ & $\begin{array}{l}-0.08 \\
(0.12)\end{array}$ & $\begin{array}{c}0.12 \\
(0.13)\end{array}$ & $\begin{array}{l}-0.05 \\
(0.20)\end{array}$ & $\begin{array}{l}-0.17 \\
(0.24)\end{array}$ & $\begin{array}{l}-0.21 \\
(0.19)\end{array}$ & 0.06 \\
\hline School Supplies Index 2011 & 950 & $\begin{array}{c}0.37 \\
(0.91)\end{array}$ & $\begin{array}{c}0.25 \\
(0.89)\end{array}$ & $\begin{array}{c}0.07 \\
(0.12)\end{array}$ & $\begin{array}{l}0.32 * * \\
(0.13)\end{array}$ & $\begin{array}{c}0.04 \\
(0.18)\end{array}$ & $\begin{array}{l}-0.12 \\
(0.20)\end{array}$ & $\begin{array}{c}0.05 \\
(0.16)\end{array}$ & 0.02 \\
\hline \multicolumn{10}{|l|}{ Panel C: Student Survey (Endline Survey - 2011) } \\
\hline School Supplies Index & 3830 & $\begin{array}{c}0.00 \\
(1.05)\end{array}$ & $\begin{array}{c}0.00 \\
(1.00)\end{array}$ & $\begin{array}{l}-0.01 \\
(0.04)\end{array}$ & $\begin{array}{l}0.09 * \\
(0.05)\end{array}$ & $\begin{array}{c}0.02 \\
(0.05)\end{array}$ & $\begin{array}{l}-0.10 \\
(0.08)\end{array}$ & $\begin{array}{l}-0.06 \\
(0.06)\end{array}$ & 0.01 \\
\hline Parental Involvement Index & 3830 & $\begin{array}{c}0.01 \\
(1.04)\end{array}$ & $\begin{array}{c}0.00 \\
(1.00)\end{array}$ & $\begin{array}{c}0.00 \\
(0.04)\end{array}$ & $\begin{array}{c}0.03 \\
(0.06)\end{array}$ & $\begin{array}{l}-0.02 \\
(0.06)\end{array}$ & $\begin{array}{l}-0.00 \\
(0.06)\end{array}$ & $\begin{array}{l}-0.01 \\
(0.06)\end{array}$ & 0.43 \\
\hline Savings Attitude Index & 3830 & $\begin{array}{c}0.05 \\
(1.00)\end{array}$ & $\begin{array}{l}-0.00 \\
(1.00)\end{array}$ & $\begin{array}{c}0.06 \\
(0.04)\end{array}$ & $\begin{array}{c}0.04 \\
(0.08)\end{array}$ & $\begin{array}{c}0.11 \\
(0.07)\end{array}$ & $\begin{array}{c}0.06 \\
(0.07)\end{array}$ & $\begin{array}{c}0.02 \\
(0.06)\end{array}$ & 0.77 \\
\hline School Fees & 3525 & $\begin{array}{c}28804 \\
(64595)\end{array}$ & $\begin{array}{c}33581 \\
(76629)\end{array}$ & $\begin{array}{l}-4816^{*} \\
(2893)\end{array}$ & $\begin{array}{c}-4104 \\
(3328)\end{array}$ & $\begin{array}{c}-6298 \\
(3831)\end{array}$ & $\begin{array}{c}-3909 \\
(3820)\end{array}$ & $\begin{array}{l}-4941 \\
(3833)\end{array}$ & 0.83 \\
\hline Primarily Used Money Earned for School Fees or Supplies & 3830 & $\begin{array}{c}0.14 \\
(0.35)\end{array}$ & $\begin{array}{c}0.12 \\
(0.32)\end{array}$ & $\begin{array}{l}0.02 * \\
(0.01)\end{array}$ & $\begin{array}{c}0.02 \\
(0.02)\end{array}$ & $\begin{array}{c}0.02 \\
(0.02)\end{array}$ & $\begin{array}{c}0.02 \\
(0.02)\end{array}$ & $\begin{array}{c}0.02 \\
(0.02)\end{array}$ & 0.97 \\
\hline Student Spent Savings on School Fees,Supplies, or Lunch & 3816 & $\begin{array}{c}0.47 \\
(0.50)\end{array}$ & $\begin{array}{c}0.40 \\
(0.49)\end{array}$ & $\begin{array}{c}0.07^{* * *} \\
(0.02)\end{array}$ & $\begin{array}{c}0.09 * * * \\
(0.03)\end{array}$ & $\begin{array}{c}0.11^{* * *} \\
(0.03)\end{array}$ & $\begin{array}{l}0.05^{*} \\
(0.03)\end{array}$ & $\begin{array}{c}0.04 \\
(0.03)\end{array}$ & 0.43 \\
\hline $\begin{array}{l}\text { Missed school because sent to look for fees or lack of } \\
\text { scholastic materials }\end{array}$ & 3575 & $\begin{array}{c}0.18 \\
(0.38)\end{array}$ & $\begin{array}{c}0.18 \\
(0.39)\end{array}$ & $\begin{array}{c}0.00 \\
(0.01)\end{array}$ & $\begin{array}{l}-0.01 \\
(0.02)\end{array}$ & $\begin{array}{c}0.00 \\
(0.02)\end{array}$ & $\begin{array}{c}0.02 \\
(0.02)\end{array}$ & $\begin{array}{l}-0.01 \\
(0.02)\end{array}$ & 0.67 \\
\hline Cost of most recent test & 2343 & $\begin{array}{l}1507 \\
(2659)\end{array}$ & $\begin{array}{l}1589 \\
(2844)\end{array}$ & $\begin{array}{c}-61 \\
(188)\end{array}$ & $\begin{array}{l}-70 \\
(273)\end{array}$ & $\begin{array}{c}76 \\
(257)\end{array}$ & $\begin{array}{l}-300 \\
(243)\end{array}$ & $\begin{array}{c}26 \\
(299)\end{array}$ & 0.95 \\
\hline
\end{tabular}

See next page for notes. 
Table 4 Notes:

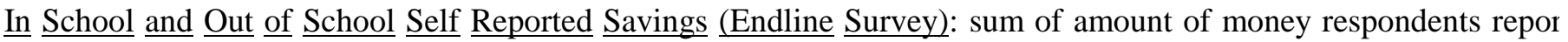
last school term in each of a variety of locations (at home in local bank, hidden at home, give to a family membe school -- which likely includes the savings held as part of the treatment, in a bank account of a family member, oth the treatment group, especially in the Cash- No Parent group, these two variables are winsorized at the 95\% level. actively used for saving: the number of locations students reported saving their money in during the last term. The $\mathrm{v}$ three locations because the survey did not record more than three; but this is not a major concern since only 5 studt reported saving in three locations, the rest saved in two or fewer. School Supplies Index (Classroom Visits): Eu classroom visits each term counted the number of students with school supplies, which was then divided by the $\mathrm{r}$ attendance. Components detailed in Appendix Table 4a. School Supplies Index (Endline Survey): a standardized categories for which at least one item is owned of the following: uniforms, notebooks, mathsets, and shoes. Co Appendix Table 4b. Parental Involvement Index includes 3 questions: 1) Student thinks parents are responsible for 2) Has your parent come to your school in the past year? 3) Has your parent seen a report of yours from sch Components detailed in Appendix Table 4b. Savings Attitude Index includes 7 statements each of which the student scale, 1-5. All scales were converted after the fact so that higher on the scale meant more positive attitude tow: money is not necessary if you live at home with your family. 2) Saving is a good thing to do. 3) Saving is for adults c relatives would be proud of me for saving. 5) Managing to save makes me feel happy with myself. 6) It's better to sp' to save it for use in the future. 7) Every time I get money I put away some money for saving. Components detailed i OLS specifications: Columns 4 amd 5-8 include robust standard errors clustered by school (the unit of random students' baseline test scores in grammar, reading, and math (not for Panel B since the dependent variable is school control for the baseline value of the dependent variable; and subcounty fixed effects (the stratification variables). B $\bar{c}$ included as controls for "School Supplies Index 2010", "School Supplies Index 2011", "School fees", and "Missed s look for fees or lack of scholastic materials" variables (others are not available at baseline). Column 9 is the psigificance on a regression of the cash parent treatment against all other treatments and the same specifications as in Ugandan Shillings, 1 USD $=2815$ UGX. ${ }^{*} \mathrm{p}<0.10{ }^{* *} \mathrm{p}<0.05{ }^{* * *} \mathrm{p}<0.01$. 
Table 5: Effect of Super Savers on Normalized Test Scores, Endline 2011

Mean (standard deviation) and OLS

\begin{tabular}{|c|c|c|c|c|c|c|c|c|c|}
\hline & $\begin{array}{c}\text { Number of } \\
\text { Obs. }\end{array}$ & $\begin{array}{r}\mathrm{M} \\
\text { (std }\end{array}$ & & $\begin{array}{c}\text { OLS (one } \\
\text { specification } \\
\text { per cell) }\end{array}$ & & $\begin{array}{r}\mathrm{OI} \\
\text { (each row }=0\end{array}$ & regression) & & P-value for test \\
\hline & $(1)$ & $\begin{array}{c}\text { Any } \\
\text { Treatment } \\
(2)\end{array}$ & $\begin{array}{c}\text { Control } \\
\text { (3) }\end{array}$ & $\begin{array}{c}\text { Any } \\
\text { Treatment } \\
\text { (4) }\end{array}$ & $\begin{array}{l}\text { Cash with } \\
\text { Parent } \\
\text { Outreach } \\
\text { (5) }\end{array}$ & $\begin{array}{c}\text { Voucher with } \\
\text { Parent } \\
\text { Outreach } \\
\text { (6) }\end{array}$ & $\begin{array}{l}\text { Cash w/o } \\
\text { Parent } \\
\text { Outreach } \\
(7)\end{array}$ & $\begin{array}{c}\text { Voucher w/o } \\
\text { Parent } \\
\text { Outreach } \\
\text { (8) }\end{array}$ & $\begin{array}{c}\text { of Cash Parent = } \\
\text { Other } \\
\text { Treatments } \\
\text { (9) }\end{array}$ \\
\hline Grammar & 3761 & $\begin{array}{c}0.05 \\
(1.05)\end{array}$ & $\begin{array}{c}-0.01 \\
(0.99)\end{array}$ & $\begin{array}{c}0.03 \\
(0.03)\end{array}$ & $\begin{array}{c}0.13^{* * *} \\
(0.04)\end{array}$ & $\begin{array}{c}0.02 \\
(0.04)\end{array}$ & $\begin{array}{c}0.04 \\
(0.05)\end{array}$ & $\begin{array}{c}-0.06 \\
(0.06)\end{array}$ & 0.00 \\
\hline Reading & 3758 & $\begin{array}{c}0.02 \\
(1.01)\end{array}$ & $\begin{array}{l}-0.00 \\
(1.00)\end{array}$ & $\begin{array}{c}0.01 \\
(0.04)\end{array}$ & $\begin{array}{l}0.11^{* *} \\
(0.05)\end{array}$ & $\begin{array}{l}-0.00 \\
(0.05)\end{array}$ & $\begin{array}{l}-0.04 \\
(0.05)\end{array}$ & $\begin{array}{l}-0.04 \\
(0.07)\end{array}$ & 0.00 \\
\hline Math & 3761 & $\begin{array}{l}-0.04 \\
(1.00)\end{array}$ & $\begin{array}{l}-0.00 \\
(1.00)\end{array}$ & $\begin{array}{l}-0.05 \\
(0.04)\end{array}$ & $\begin{array}{c}0.01 \\
(0.05)\end{array}$ & $\begin{array}{l}-0.10^{* *} \\
(0.04)\end{array}$ & $\begin{array}{l}-0.01 \\
(0.05)\end{array}$ & $\begin{array}{l}-0.08 \\
(0.07)\end{array}$ & 0.11 \\
\hline Total & 3758 & $\begin{array}{c}0.01 \\
(1.02)\end{array}$ & $\begin{array}{l}-0.00 \\
(1.00)\end{array}$ & $\begin{array}{c}0.00 \\
(0.03)\end{array}$ & $\begin{array}{l}0.10^{* *} \\
(0.04)\end{array}$ & $\begin{array}{l}-0.02 \\
(0.04)\end{array}$ & $\begin{array}{l}-0.00 \\
(0.04)\end{array}$ & $\begin{array}{l}-0.06 \\
(0.07)\end{array}$ & 0.00 \\
\hline
\end{tabular}

OLS specifications: Columns 4 and 5-8 include robust standard errors clustered by school (the unit of randomization); controls for students' baseline test scores in grammar, reading, and math; and subcounty fixed effects (the stratification variables). Column 9 is the p-value of an F-test of sigificance on a regression of the cash parent treatment against all other treatments and the same specifications as in Columns 5-8. ${ }^{*} \mathrm{p}<0.10$ ${ }^{* *} \mathrm{p}<0.05 * * * \mathrm{p}<0.01$. 
Table 6: Effect of Super Savers on School Participation

Mean (standard deviation) and OLS

\begin{tabular}{|c|c|c|c|c|c|c|c|c|c|}
\hline & \multirow{2}{*}{$\begin{array}{c}\text { Number } \\
\text { of Obs. } \\
\text { (1) }\end{array}$} & \multicolumn{2}{|c|}{$\begin{array}{c}\text { Mean } \\
\text { (std dev) }\end{array}$} & \multirow{2}{*}{$\begin{array}{c}\text { OLS (one } \\
\text { specification } \\
\text { per cell) } \\
\text { Any } \\
\text { Treatment } \\
(4) \\
\end{array}$} & \multicolumn{4}{|c|}{$\begin{array}{c}\text { OLS } \\
\text { (each row }=\text { one regression) }\end{array}$} & \multirow[b]{2}{*}{$\begin{array}{c}\text { P-value for test } \\
\text { of Cash Parent = } \\
\text { Other } \\
\text { Treatments } \\
\text { (9) }\end{array}$} \\
\hline & & $\begin{array}{c}\text { Any } \\
\text { Treatment } \\
(2) \\
\end{array}$ & $\begin{array}{c}\text { Control } \\
(3)\end{array}$ & & $\begin{array}{c}\text { Cash with } \\
\text { Parent } \\
\text { Outreach } \\
\text { (5) } \\
\end{array}$ & $\begin{array}{c}\text { Voucher with } \\
\text { Parent } \\
\text { Outreach } \\
(6) \\
\end{array}$ & $\begin{array}{c}\text { Cash w/o } \\
\text { Parent } \\
\text { Outreach } \\
(7) \\
\end{array}$ & $\begin{array}{c}\text { Voucher w/o } \\
\text { Parent } \\
\text { Outreach } \\
(8) \\
\end{array}$ & \\
\hline \multicolumn{10}{|l|}{ Panel A: Attendance rate } \\
\hline 2010 & 4707 & $\begin{array}{c}0.34 \\
(0.42)\end{array}$ & $\begin{array}{c}0.35 \\
(0.42)\end{array}$ & $\begin{array}{l}-0.02 \\
(0.03)\end{array}$ & $\begin{array}{l}-0.06 \\
(0.04)\end{array}$ & $\begin{array}{l}-0.02 \\
(0.04)\end{array}$ & $\begin{array}{l}-0.03 \\
(0.04)\end{array}$ & $\begin{array}{c}0.02 \\
(0.04)\end{array}$ & 0.22 \\
\hline 2011 & 4707 & $\begin{array}{c}0.18 \\
(0.36)\end{array}$ & $\begin{array}{c}0.17 \\
(0.35)\end{array}$ & $\begin{array}{c}0.00 \\
(0.02)\end{array}$ & $\begin{array}{l}-0.02 \\
(0.03)\end{array}$ & $\begin{array}{c}0.00 \\
(0.03)\end{array}$ & $\begin{array}{c}0.02 \\
(0.03)\end{array}$ & $\begin{array}{c}0.01 \\
(0.02)\end{array}$ & 0.38 \\
\hline Overall (2010 \& 2011 combined) & 4707 & $\begin{array}{c}0.28 \\
(0.36)\end{array}$ & $\begin{array}{c}0.28 \\
(0.36)\end{array}$ & $\begin{array}{l}-0.01 \\
(0.02)\end{array}$ & $\begin{array}{l}-0.04 \\
(0.03)\end{array}$ & $\begin{array}{l}-0.01 \\
(0.03)\end{array}$ & $\begin{array}{l}-0.01 \\
(0.03)\end{array}$ & $\begin{array}{c}0.01 \\
(0.03)\end{array}$ & 0.24 \\
\hline Attendance Index & 2926 & $\begin{array}{l}-0.02 \\
(0.98)\end{array}$ & $\begin{array}{l}-0.00 \\
(1.00)\end{array}$ & $\begin{array}{l}-0.01 \\
(0.05)\end{array}$ & $\begin{array}{c}0.00 \\
(0.07)\end{array}$ & $\begin{array}{c}0.02 \\
(0.07)\end{array}$ & $\begin{array}{l}-0.05 \\
(0.07)\end{array}$ & $\begin{array}{l}-0.04 \\
(0.06)\end{array}$ & 0.51 \\
\hline \multicolumn{10}{|l|}{ Panel B: Enrollment rate } \\
\hline 2010 & 4707 & $\begin{array}{c}0.43 \\
(0.50)\end{array}$ & $\begin{array}{c}0.45 \\
(0.50)\end{array}$ & $\begin{array}{l}-0.03 \\
(0.03)\end{array}$ & $\begin{array}{l}-0.08 \\
(0.05)\end{array}$ & $\begin{array}{l}-0.03 \\
(0.05)\end{array}$ & $\begin{array}{l}-0.02 \\
(0.05)\end{array}$ & $\begin{array}{c}0.03 \\
(0.05)\end{array}$ & 0.14 \\
\hline 2011 & 4707 & $\begin{array}{c}0.22 \\
(0.41)\end{array}$ & $\begin{array}{c}0.22 \\
(0.41)\end{array}$ & $\begin{array}{l}-0.00 \\
(0.02)\end{array}$ & $\begin{array}{l}-0.03 \\
(0.04)\end{array}$ & $\begin{array}{l}-0.00 \\
(0.03)\end{array}$ & $\begin{array}{c}0.02 \\
(0.04)\end{array}$ & $\begin{array}{l}-0.01 \\
(0.03)\end{array}$ & 0.34 \\
\hline
\end{tabular}

Attendance Rate: Based on a roll call of students on the official school enrollment list, counting only those students present in the class when roll call was done. Attendance Index: includes 3 self-reported questions on student attendance: 1) Of the five school days of last week, how many were you absent? 2) Think of a normal week from last term, of the five school days how many were you usually absent from school? 3) Think of a normal month from last term, how many days were you usually absent? Components detailed in Appendix Table 4d. Enrollment Rate: Based on teacher responses as to whether a student on the official school enrollment list, was still enrolled at that school. OLS specifications: Columns 4 and 5-8 include robust standard errors clustered by school (the unit of randomization); controls for students' baseline test scores in grammar, reading, and math; if available, a control for the baseline value of the dependent variable; and subcounty fixed effects (the stratification variables). Here, baseline values are available only for "Attendance Index" variable. Column 9 is the p-value of an F-test of sigificance on a regression of the cash parent treatment against all other treatments and the same specifications as in Columns $5-8{ }^{*} \mathrm{p}<0.10 * * \mathrm{p}<0.05{ }^{* * *} \mathrm{p}<0.01$. 
Table 7: Effect of Super Savers on Student Attitudes, Endline 2011

Mean (standard deviation) and OLS

\begin{tabular}{|c|c|c|c|c|c|c|c|c|c|}
\hline & \multirow{2}{*}{$\begin{array}{c}\text { Number } \\
\text { of Obs. } \\
\text { (1) }\end{array}$} & \multicolumn{2}{|c|}{$\begin{array}{c}\text { Mean } \\
\text { (std dev) }\end{array}$} & \multirow{2}{*}{$\begin{array}{c}\text { OLS (one } \\
\text { specification } \\
\text { per cell) } \\
\\
\text { Any } \\
\text { Treatment } \\
\text { (4) }\end{array}$} & \multicolumn{4}{|c|}{$\begin{array}{c}\text { OLS } \\
\text { (each row }=\text { one regression) }\end{array}$} & \multirow{2}{*}{$\begin{array}{c}\text { P-value for } \\
\text { test of Cash } \\
\text { Parent }= \\
\text { Other } \\
\text { Treatments } \\
\text { (9) }\end{array}$} \\
\hline & & $\begin{array}{c}\text { Any } \\
\text { Treatment } \\
\text { (2) }\end{array}$ & $\begin{array}{l}\text { Control } \\
\text { (3) }\end{array}$ & & $\begin{array}{l}\text { Cash with } \\
\text { Parent } \\
\text { Outreach } \\
\text { (5) }\end{array}$ & $\begin{array}{c}\text { Voucher } \\
\text { with Parent } \\
\text { Outreach } \\
\text { (6) }\end{array}$ & $\begin{array}{c}\text { Cash w/o } \\
\text { Parent } \\
\text { Outreach } \\
\text { (7) }\end{array}$ & $\begin{array}{c}\text { Voucher } \\
\text { w/o Parent } \\
\text { Outreach } \\
\text { (8) }\end{array}$ & \\
\hline Self Esteem Index & 3830 & $\begin{array}{l}-0.02 \\
(0.44)\end{array}$ & $\begin{array}{l}-0.00 \\
(0.44)\end{array}$ & $\begin{array}{l}-0.03 \\
(0.02)\end{array}$ & $\begin{array}{c}-0.05^{* *} \\
(0.02)\end{array}$ & $\begin{array}{l}-0.03 \\
(0.02)\end{array}$ & $\begin{array}{l}-0.03 \\
(0.03)\end{array}$ & $\begin{array}{l}-0.01 \\
(0.03)\end{array}$ & 0.25 \\
\hline Time Preference Index & 3820 & $\begin{array}{c}2.05 \\
(0.83)\end{array}$ & $\begin{array}{c}2.07 \\
(0.82)\end{array}$ & $\begin{array}{l}-0.02 \\
(0.03)\end{array}$ & $\begin{array}{l}-0.02 \\
(0.04)\end{array}$ & $\begin{array}{l}-0.02 \\
(0.04)\end{array}$ & $\begin{array}{l}-0.00 \\
(0.04)\end{array}$ & $\begin{array}{l}-0.03 \\
(0.04)\end{array}$ & 0.99 \\
\hline Locus of Control (binary) & 3818 & $\begin{array}{c}0.58 \\
(0.49)\end{array}$ & $\begin{array}{c}0.60 \\
(0.49)\end{array}$ & $\begin{array}{l}-0.02 \\
(0.02)\end{array}$ & $\begin{array}{l}-0.01 \\
(0.02)\end{array}$ & $\begin{array}{l}-0.02 \\
(0.02)\end{array}$ & $\begin{array}{l}-0.01 \\
(0.02)\end{array}$ & $\begin{array}{l}-0.03 \\
(0.02)\end{array}$ & 0.74 \\
\hline Financial Independence Index & 3830 & $\begin{array}{l}-0.04 \\
(0.97)\end{array}$ & $\begin{array}{c}0.00 \\
(1.00)\end{array}$ & $\begin{array}{l}-0.03 \\
(0.04)\end{array}$ & $\begin{array}{l}-0.05 \\
(0.06)\end{array}$ & $\begin{array}{l}-0.13^{* *} \\
(0.06)\end{array}$ & $\begin{array}{c}0.06 \\
(0.06)\end{array}$ & $\begin{array}{l}-0.00 \\
(0.05)\end{array}$ & 0.65 \\
\hline Aspirations Index & 3830 & $\begin{array}{c}-0.01 \\
(1.04)\end{array}$ & $\begin{array}{c}0.00 \\
(1.00)\end{array}$ & $\begin{array}{c}-0.03 \\
(0.04)\end{array}$ & $\begin{array}{l}-0.05 \\
(0.06)\end{array}$ & $\begin{array}{c}-0.03 \\
(0.06)\end{array}$ & $\begin{array}{c}0.02 \\
(0.04)\end{array}$ & $\begin{array}{c}-0.04 \\
(0.06)\end{array}$ & 0.54 \\
\hline Total annual hours worked, wins. 99\% & 3830 & $\begin{array}{c}295.33 \\
(461.85)\end{array}$ & $\begin{array}{c}294.96 \\
(447.26)\end{array}$ & $\begin{array}{c}6.88 \\
(17.30)\end{array}$ & $\begin{array}{c}1.01 \\
(23.20)\end{array}$ & $\begin{array}{c}-31.78 \\
(27.91)\end{array}$ & $\begin{array}{c}36.02 \\
(29.26)\end{array}$ & $\begin{array}{c}21.96 \\
(26.04)\end{array}$ & 0.75 \\
\hline Total annual income from work (10k UGX), wins. 99\% & 3830 & $\begin{array}{c}17.55 \\
(34.42)\end{array}$ & $\begin{array}{c}17.82 \\
(33.91)\end{array}$ & $\begin{array}{c}0.20 \\
(1.36)\end{array}$ & $\begin{array}{c}-1.50 \\
(1.76)\end{array}$ & $\begin{array}{c}-2.88 \\
(2.18)\end{array}$ & $\begin{array}{l}4.03^{*} \\
(2.08)\end{array}$ & $\begin{array}{c}1.17 \\
(2.00)\end{array}$ & 0.21 \\
\hline
\end{tabular}

Self Esteem Index: includes 10 statements each of which the student evaluated on a Likert scale, 1-5. All scales were converted after the fact so that higher on the scale meant higher self esteem. 1) I am satisfied with myself. 2) Sometimes I think I am no good at all. 3) I believe I have a number of good qualities. 4) I am able to do things as well as most children. 5) I do not have much to be proud of. 6) Sometimes I feel useless. 7) I believe I am a valuable person, at least as much as my classmates. 8) I wish I could have more respect for myself 9) I sometimes think that I am a failure. 10) When I think of myself, I usually think good thoughts. In addition to those 10 statements, there is one question: 11) Are you confident that you will be successful in the future? Components detailed in Appendix Table 4e. Time Preference Index: includes 2 hypothetical time preference choices. 1) Would you rather receive 500 shillings today or 800 shillings next week? 2) Would you rather receive 500 shillings today or 1,000 shillings next week? From these, respondents were split into low, medium, and high future preference groups. Components detailed in Appendix Table 4f. Locus of Control: If a person is successful in life, is it because he or she was lucky or because he or she worked very hard? (1=worked hard, $0=$ lucky) Financial Independence Index: includes 3 questions: 1) How much money do you think you will get in the next 7 days? 2) How much money did you get in the past 7 days? 3) How much pocket money are you given to spend as you wish? Components detailed in Appendix Table 4f. Aspirations Index: includes 4 questions about academic and vocation aspirations: 1) If you graduate from primary school, will your life be better than if you hadn't graduated? 2) Do you think you will go to secondary school? 3) Do you think you will reach university? 4) What do you want to be when you grow up? (student responded with career that requires higher education) Components detailed in Appendix Table 4f. OLS specifications: Columns 4 amd 5-8 include robust standard errors clustered by school (the unit of randomization); controls for students' baseline test scores in grammar, reading, and math; if available, a control for the baseline value of the dependent variable; and subcounty fixed effects (the stratification variables). Here, Here, baseline values are available only for "Time Prefernce Index" variable. Column 9 is the p-value of an F-test of sigificance on a regression of the cash parent treatment against all other treatments and the same specifications as in Columns 5-8. UGX = Ugandan Shillings, 1 USD $=2815$ UGX. ${ }^{*} \mathrm{p}<0.10 * * \mathrm{p}<0.05 * * * \mathrm{p}<0.01$. 
Appendix Table 1: Summary Statistics of Annual School Fees

\begin{tabular}{|c|c|c|c|c|c|c|c|c|c|}
\hline & & $\begin{array}{c}\text { Number } \\
\text { of Obs. } \\
(1)\end{array}$ & $\begin{array}{c}\text { Mean } \\
(2) \\
\end{array}$ & $\begin{array}{c}\text { Std Dev } \\
\text { (3) }\end{array}$ & $\begin{array}{c}\text { Min } \\
(4) \\
\end{array}$ & $\begin{array}{c}\text { 25th } \\
\text { Percentile } \\
(5) \\
\end{array}$ & $\begin{array}{c}\text { Median } \\
(6) \\
\end{array}$ & $\begin{array}{c}\text { 75th } \\
\text { Percentile } \\
(7) \\
\end{array}$ & $\begin{array}{c}\text { Max. } \\
(8)\end{array}$ \\
\hline \multicolumn{10}{|c|}{ Panel A: Annual School Fees for Each Student (in USD), winsorized at 90\% } \\
\hline Total of All Fees & & 3585 & 13.0 & 13.4 & 0.0 & 2.7 & 6.8 & 20.6 & 40.5 \\
\hline General Fee & & 3583 & 7.0 & 11.1 & 0.0 & 0.0 & 0.0 & 11.7 & 29.8 \\
\hline \multirow[t]{3}{*}{ Food Fees } & & 3584 & 1.2 & 1.7 & 0.0 & 0.0 & 0.1 & 1.8 & 4.9 \\
\hline & Lunch Fee & 3584 & 0.9 & 1.5 & 0.0 & 0.0 & 0.0 & 1.2 & 4.3 \\
\hline & Chef/Grinding Fee & 3583 & 0.2 & 0.4 & 0.0 & 0.0 & 0.0 & 0.0 & 1.1 \\
\hline \multirow[t]{4}{*}{ Testing Fees } & & 3584 & 2.1 & 2.5 & 0.0 & 0.0 & 1.1 & 3.2 & 7.5 \\
\hline & Standardized Test Fee & 3583 & 1.0 & 1.7 & 0.0 & 0.0 & 0.0 & 1.3 & 5.0 \\
\hline & Practice Test Fee & 3584 & 0.5 & 0.7 & 0.0 & 0.0 & 0.0 & 1.1 & 1.6 \\
\hline & Test Paper Fee & 3583 & 0.0 & 0.0 & 0.0 & 0.0 & 0.0 & 0.0 & 0.0 \\
\hline \multicolumn{2}{|c|}{ School Infrastructure Fees } & 3584 & 0.2 & 0.4 & 0.0 & 0.0 & 0.0 & 0.0 & 1.1 \\
\hline & Development Fee & 3583 & 0.1 & 0.3 & 0.0 & 0.0 & 0.0 & 0.0 & 0.9 \\
\hline & School Necessities Fee & 3584 & 0.0 & 0.0 & 0.0 & 0.0 & 0.0 & 0.0 & 0.0 \\
\hline Extra Lessons Fe & & 3583 & 0.4 & 1.0 & 0.0 & 0.0 & 0.0 & 0.0 & 3.2 \\
\hline \multicolumn{10}{|c|}{ Panel B: Average Annual School Fees per Student for Each School (in USD), winsorized at $90 \%$} \\
\hline \multicolumn{2}{|c|}{ Total of All Fees } & 136 & 16.2 & 10.2 & 2.9 & 8.5 & 13.4 & 20.7 & 38.3 \\
\hline \multicolumn{2}{|l|}{ General Fee } & 136 & 10.5 & 9.3 & 0.0 & 3.8 & 7.8 & 12.6 & 31.8 \\
\hline \multirow[t]{3}{*}{ Food Fees } & & 136 & 2.2 & 1.9 & 0.0 & 0.9 & 1.6 & 2.7 & 6.4 \\
\hline & Lunch Fee & 136 & 1.9 & 1.9 & 0.0 & 0.6 & 1.0 & 2.2 & 6.4 \\
\hline & Chef/Grinding Fee & 136 & 0.3 & 0.3 & 0.0 & 0.0 & 0.2 & 0.5 & 0.7 \\
\hline \multirow[t]{4}{*}{ Testing Fees } & & 136 & 2.4 & 1.1 & 0.0 & 1.5 & 2.2 & 3.3 & 4.2 \\
\hline & Standardized Test Fee & 136 & 1.3 & 0.8 & 0.0 & 0.6 & 1.2 & 1.9 & 2.7 \\
\hline & Practice Test Fee & 136 & 0.7 & 0.5 & 0.0 & 0.3 & 0.7 & 1.1 & 1.5 \\
\hline & Test Paper Fee & 136 & 0.3 & 0.5 & 0.0 & 0.0 & 0.0 & 0.6 & 1.4 \\
\hline \multicolumn{2}{|c|}{ School Infrastructure Fees } & 136 & 0.3 & 0.3 & 0.0 & 0.0 & 0.2 & 0.5 & 1.0 \\
\hline & Development Fee & 136 & 0.2 & 0.3 & 0.0 & 0.0 & 0.1 & 0.4 & 0.8 \\
\hline & School Necessities Fee & 136 & 0.1 & 0.1 & 0.0 & 0.0 & 0.0 & 0.1 & 0.2 \\
\hline \multicolumn{2}{|c|}{ Extra Lessons Fee } & 136 & 0.7 & 0.8 & 0.0 & 0.0 & 0.3 & 1.0 & 2.5 \\
\hline
\end{tabular}

The data here incorporate student-reported fees across three terms. Numbers are in USD, converted from UGX in Sept 2011 (when endline survey was conducted) at 2815UGX $=1$ USD. General Fee: A fee required to attend school. Because the government discourages General Fees, most schools do not charge them, but some schools, especially in urban areas still do. Food Fees: Include lunch fees and chef/grinding fees. The chef/grinding fee can either be monetary or in-kind (e.g., maize). We imputed the value of maize at $450 \mathrm{UGX} / \mathrm{kg}$. Testing Fees: Include standardized test fees, practice test fees, and test paper fees. Practice test fee is often optional. School Infrastructure Fees: Include Development Fee and School Necessities Fee. The Development Fee is generally for infrastructure projects such as latrines, building repair, etc. The School Necessities Fee includes recurring costs such as toilet paper (and other supplies) and utilities. 
Appendix Table 2: Data Collection Summary

\begin{tabular}{lccc}
\hline \hline & 2010 & 2011 & 2012 \\
\hline Student Survey & & & \\
$\quad$ Grades Covered & P5, P6 & P6, P7 & \\
Median age & 12,13 & 13,14 & \\
Sample Size (Students) & 4716 & 3838 & \\
& & & \\
Attendance Survey & & & \\
Grades Covered & P5, P6 & P6, P7 & \\
Median age & 12,13 & 13,14 & \\
Sample Size (Students) & 37797 & 29038 & \\
& & & \\
Classroom Survey & & & \\
$\quad$ Grades Covered & P5, P6, P7 & P5, P6, P7 & P5, P6, P7 \\
Median age & $12,13,14$ & $12,13,14$ & $12,13,14$ \\
Sample Size (Classes) & 406 & 408 & 340 \\
\hline
\end{tabular}


Appendix Table 3: Additional Attrition Analysis

OLS

\begin{tabular}{|c|c|c|c|c|c|c|}
\hline Dependent variable: & $\begin{array}{c}\text { Endline Survey } \\
\text { Completed } \\
(1)\end{array}$ & $\begin{array}{c}\text { Endline Survey } \\
\text { Completed } \\
\text { (2) }\end{array}$ & $\begin{array}{c}\text { Endline Survey } \\
\text { Completed } \\
\text { (3) }\end{array}$ & $\begin{array}{c}\text { Endline Test } \\
\text { Completed } \\
\text { (4) }\end{array}$ & $\begin{array}{c}\text { Endline Test } \\
\text { Completed } \\
\text { (5) }\end{array}$ & $\begin{array}{c}\text { Endline Test } \\
\text { Completed } \\
(6)\end{array}$ \\
\hline Cash with Parent Outreach & $\begin{array}{c}0.01 \\
(0.02)\end{array}$ & $\begin{array}{c}0.00 \\
(0.02)\end{array}$ & $\begin{array}{l}-0.00 \\
(0.07)\end{array}$ & $\begin{array}{c}0.01 \\
(0.02)\end{array}$ & $\begin{array}{c}0.00 \\
(0.02)\end{array}$ & $\begin{array}{l}-0.02 \\
(0.08)\end{array}$ \\
\hline Cash w/o Parent Outreach & $\begin{array}{l}-0.01 \\
(0.02)\end{array}$ & $\begin{array}{l}-0.01 \\
(0.02)\end{array}$ & $\begin{array}{c}0.05 \\
(0.08)\end{array}$ & $\begin{array}{c}0.00 \\
(0.02)\end{array}$ & $\begin{array}{l}-0.00 \\
(0.02)\end{array}$ & $\begin{array}{c}0.02 \\
(0.08)\end{array}$ \\
\hline Voucher with Parent Outreach & $\begin{array}{c}0.00 \\
(0.02)\end{array}$ & $\begin{array}{c}0.01 \\
(0.02)\end{array}$ & $\begin{array}{c}0.06 \\
(0.07)\end{array}$ & $\begin{array}{c}0.01 \\
(0.02)\end{array}$ & $\begin{array}{c}0.01 \\
(0.02)\end{array}$ & $\begin{array}{c}0.03 \\
(0.08)\end{array}$ \\
\hline Voucher w/o Parent Outreach & $\begin{array}{c}0.02 \\
(0.02)\end{array}$ & $\begin{array}{c}0.01 \\
(0.02)\end{array}$ & $\begin{array}{c}0.06 \\
(0.07)\end{array}$ & $\begin{array}{c}0.02 \\
(0.02)\end{array}$ & $\begin{array}{c}0.01 \\
(0.02)\end{array}$ & $\begin{array}{c}0.02 \\
(0.06)\end{array}$ \\
\hline Constant & $\begin{array}{c}0.76^{* * *} \\
(0.02)\end{array}$ & $\begin{array}{c}0.71^{* * *} \\
(0.04)\end{array}$ & $\begin{array}{c}0.69 * * * \\
(0.05)\end{array}$ & $\begin{array}{c}0.75^{* * *} \\
(0.02)\end{array}$ & $\begin{array}{c}0.69 * * * \\
(0.04)\end{array}$ & $\begin{array}{c}0.69 * * * \\
(0.06)\end{array}$ \\
\hline Observations & 4716 & 3832 & 3832 & 4716 & 3832 & 3832 \\
\hline Covariates & No & Yes & Yes & No & Yes & Yes \\
\hline $\begin{array}{l}\text { Interactions between each covariate and each } \\
\text { treatment variable }\end{array}$ & No & No & Yes & No & No & Yes \\
\hline $\begin{array}{l}\text { Control mean } \\
\text { (Control sd) }\end{array}$ & $\begin{array}{c}0.81 \\
(0.39)\end{array}$ & $\begin{array}{c}0.81 \\
(0.39)\end{array}$ & $\begin{array}{c}0.81 \\
(0.39)\end{array}$ & $\begin{array}{c}0.80 \\
(0.40)\end{array}$ & $\begin{array}{c}0.80 \\
(0.40)\end{array}$ & $\begin{array}{c}0.80 \\
(0.40)\end{array}$ \\
\hline $\begin{array}{l}\text { F-test (p-value) of joint significance of the four } \\
\text { treatment assignments }\end{array}$ & $\begin{array}{c}0.58 \\
(0.68)\end{array}$ & $\begin{array}{c}0.37 \\
(0.83)\end{array}$ & & $\begin{array}{c}0.23 \\
(0.92)\end{array}$ & $\begin{array}{c}0.08 \\
(0.99)\end{array}$ & \\
\hline $\begin{array}{l}\text { F-test (p-value) of joint significance of interaction } \\
\text { terms of each covariate with each treatment }\end{array}$ & & & $\begin{array}{c}1.35 \\
(0.10)\end{array}$ & & & $\begin{array}{c}1.47 \\
(0.05)\end{array}$ \\
\hline
\end{tabular}

OLS specifications: Columns 1-6 include robust standard errors clustered by school (the unit of randomization) and subcounty fixed effects (the stratification variables). Additionally, regressions reported in columns 2 and 5 include the following covariates from the baseline: test scores in grammar, reading, and math, attendance code, how often student misses the school, questions on time preference, whether the student gets any pocket money, amount of pocket money if they get any (winsorized at 99th percentile), if the student earns any money, and the amount of money earned (winsorized at 99th percentile). Regressions in columns 3 and 6 include these covariates and their interactions with the four treatment arms. ${ }^{*} \mathrm{p}<0.10 * * \mathrm{p}<0.05 * * * \mathrm{p}<0.01$ 
Appendix Table 4a: Components of Table 4, Panel B, School Supplies Index

Mean (standard deviation) and OLS

\begin{tabular}{|c|c|c|c|c|c|c|c|c|c|}
\hline & \multirow{2}{*}{$\begin{array}{c}\text { Number of } \\
\text { Obs. } \\
\text { (1) }\end{array}$} & \multirow{2}{*}{\multicolumn{3}{|c|}{$\begin{array}{l}\text { OLS (one } \\
\text { specification } \\
\text { per cell) } \\
\\
\text { Any } \\
\text { Treatment } \\
\text { (4) }\end{array}$}} & \multicolumn{4}{|c|}{$\begin{array}{c}\text { OLS } \\
\text { (each row = one regression) } \\
\text { Voucher }\end{array}$} & \multirow{2}{*}{$\begin{array}{l}\text { P-value for } \\
\text { test of Cash } \\
\text { Parent = } \\
\text { Other } \\
\text { Treatments } \\
\text { (9) }\end{array}$} \\
\hline & & & & & $\begin{array}{l}\text { Cash with } \\
\text { Parent } \\
\text { Outreach } \\
\text { (5) }\end{array}$ & $\begin{array}{c}\text { with } \\
\text { Parent } \\
\text { Outreach } \\
\text { (6) }\end{array}$ & $\begin{array}{c}\text { Cash w/o } \\
\text { Parent } \\
\text { Outreach } \\
\text { (7) }\end{array}$ & $\begin{array}{c}\text { Voucher } \\
\text { w/o Parent } \\
\text { Outreach } \\
\text { (8) }\end{array}$ & \\
\hline \multicolumn{10}{|c|}{ Panel A: School Supplies Index \& Components (Classroom Surveys 2010 and 2011) } \\
\hline $\begin{array}{l}\text { School Supplies } \\
\text { Index (2010) }\end{array}$ & 813 & $\begin{array}{c}-0.16 \\
(1.18)\end{array}$ & $\begin{array}{l}-0.10 \\
(0.89)\end{array}$ & $\begin{array}{c}-0.08 \\
(0.12)\end{array}$ & $\begin{array}{c}0.12 \\
(0.13)\end{array}$ & $\begin{array}{l}-0.05 \\
(0.20)\end{array}$ & $\begin{array}{l}-0.17 \\
(0.24)\end{array}$ & $\begin{array}{l}-0.21 \\
(0.19)\end{array}$ & 0.06 \\
\hline Shoes & 813 & $\begin{array}{c}0.25 \\
(0.26)\end{array}$ & $\begin{array}{c}0.25 \\
(0.26)\end{array}$ & $\begin{array}{c}0.00 \\
(0.02)\end{array}$ & $\begin{array}{c}0.00 \\
(0.03)\end{array}$ & $\begin{array}{l}0.04 * \\
(0.03)\end{array}$ & $\begin{array}{l}-0.04 \\
(0.04)\end{array}$ & $\begin{array}{c}0.00 \\
(0.03)\end{array}$ & 0.99 \\
\hline Uniform & 813 & $\begin{array}{c}0.85 \\
(0.11)\end{array}$ & $\begin{array}{c}0.84 \\
(0.12)\end{array}$ & $\begin{array}{l}-0.01 \\
(0.02)\end{array}$ & $\begin{array}{l}-0.00 \\
(0.02)\end{array}$ & $\begin{array}{c}0.01 \\
(0.02)\end{array}$ & $\begin{array}{l}-0.03 \\
(0.04)\end{array}$ & $\begin{array}{l}-0.01 \\
(0.03)\end{array}$ & 0.70 \\
\hline Math Set & 813 & $\begin{array}{c}0.38 \\
(0.11)\end{array}$ & $\begin{array}{c}0.36 \\
(0.10)\end{array}$ & $\begin{array}{c}0.01 \\
(0.01)\end{array}$ & $\begin{array}{c}0.03 \\
(0.02)\end{array}$ & $\begin{array}{c}0.00 \\
(0.02)\end{array}$ & $\begin{array}{l}-0.01 \\
(0.03)\end{array}$ & $\begin{array}{c}0.01 \\
(0.02)\end{array}$ & 0.24 \\
\hline Pencils & 813 & $\begin{array}{c}0.99 \\
(0.03)\end{array}$ & $\begin{array}{c}0.99 \\
(0.04)\end{array}$ & $\begin{array}{c}0.00 \\
(0.00)\end{array}$ & $\begin{array}{c}0.00 \\
(0.00)\end{array}$ & $\begin{array}{c}0.00 \\
(0.00)\end{array}$ & $\begin{array}{c}0.00 \\
(0.00)\end{array}$ & $\begin{array}{l}-0.00 \\
(0.01)\end{array}$ & 0.35 \\
\hline Exercise Book & 813 & $\begin{array}{c}0.99 \\
(0.04)\end{array}$ & $\begin{array}{c}1.00 \\
(0.02)\end{array}$ & $\begin{array}{l}-0.00 \\
(0.00)\end{array}$ & $\begin{array}{c}0.00 \\
(0.00)\end{array}$ & $\begin{array}{l}-0.01 \\
(0.01)\end{array}$ & $\begin{array}{c}0.00 \\
(0.00)\end{array}$ & $\begin{array}{l}-0.01 \\
(0.01)\end{array}$ & 0.10 \\
\hline $\begin{array}{l}\text { School Supplies } \\
\text { Index (2011) }\end{array}$ & 950 & $\begin{array}{c}0.37 \\
(0.91)\end{array}$ & $\begin{array}{c}0.25 \\
(0.89)\end{array}$ & $\begin{array}{c}0.07 \\
(0.12)\end{array}$ & $\begin{array}{l}0.32 * * \\
(0.13)\end{array}$ & $\begin{array}{c}0.04 \\
(0.18)\end{array}$ & $\begin{array}{l}-0.12 \\
(0.20)\end{array}$ & $\begin{array}{c}0.05 \\
(0.16)\end{array}$ & 0.02 \\
\hline Shoes & 950 & $\begin{array}{c}0.35 \\
(0.26)\end{array}$ & $\begin{array}{c}0.32 \\
(0.24)\end{array}$ & $\begin{array}{c}0.03 \\
(0.02)\end{array}$ & $\begin{array}{c}0.04 \\
(0.03)\end{array}$ & $\begin{array}{l}0.05^{*} \\
(0.03)\end{array}$ & $\begin{array}{c}0.00 \\
(0.03)\end{array}$ & $\begin{array}{c}0.03 \\
(0.03)\end{array}$ & 0.61 \\
\hline Uniform & 950 & $\begin{array}{c}0.88 \\
(0.11)\end{array}$ & $\begin{array}{c}0.86 \\
(0.11)\end{array}$ & $\begin{array}{l}-0.00 \\
(0.02)\end{array}$ & $\begin{array}{l}0.03^{* *} \\
(0.02)\end{array}$ & $\begin{array}{l}-0.01 \\
(0.03)\end{array}$ & $\begin{array}{l}-0.03 \\
(0.04)\end{array}$ & $\begin{array}{c}0.00 \\
(0.03)\end{array}$ & 0.02 \\
\hline Math Set & 950 & $\begin{array}{c}0.44 \\
(0.13)\end{array}$ & $\begin{array}{c}0.44 \\
(0.12)\end{array}$ & $\begin{array}{l}-0.00 \\
(0.01)\end{array}$ & $\begin{array}{c}0.01 \\
(0.02)\end{array}$ & $\begin{array}{l}-0.00 \\
(0.02)\end{array}$ & $\begin{array}{l}-0.00 \\
(0.02)\end{array}$ & $\begin{array}{l}-0.01 \\
(0.02)\end{array}$ & 0.38 \\
\hline Exercise Book & 950 & $\begin{array}{c}0.90 \\
(0.09)\end{array}$ & $\begin{array}{c}0.90 \\
(0.11)\end{array}$ & $\begin{array}{c}0.02 \\
(0.02)\end{array}$ & $\begin{array}{c}0.06^{* *} \\
(0.02)\end{array}$ & $\begin{array}{c}0.00 \\
(0.03)\end{array}$ & $\begin{array}{l}-0.00 \\
(0.03)\end{array}$ & $\begin{array}{c}0.01 \\
(0.02)\end{array}$ & 0.01 \\
\hline
\end{tabular}

OLS specifications: Columns 4 amd 5-8 include robust standard errors clustered by school (the unit of randomization), control for baseline supplies index, and subcounty fixed effects (the stratification variables). Column 9 is the p-value of an F-test of sigificance on a regression of the cash parent treatment against all other treatments and the same specifications as in Columns 5 -8. $*$ p $<0.10 * *$ $\mathrm{p}<0.05 * * * \mathrm{p}<0.01$ 
Appendix Table 4b: Components of Table 4, Panel C, Student Survey Indices, Endline 2011

Mean (standard deviation) and OLS

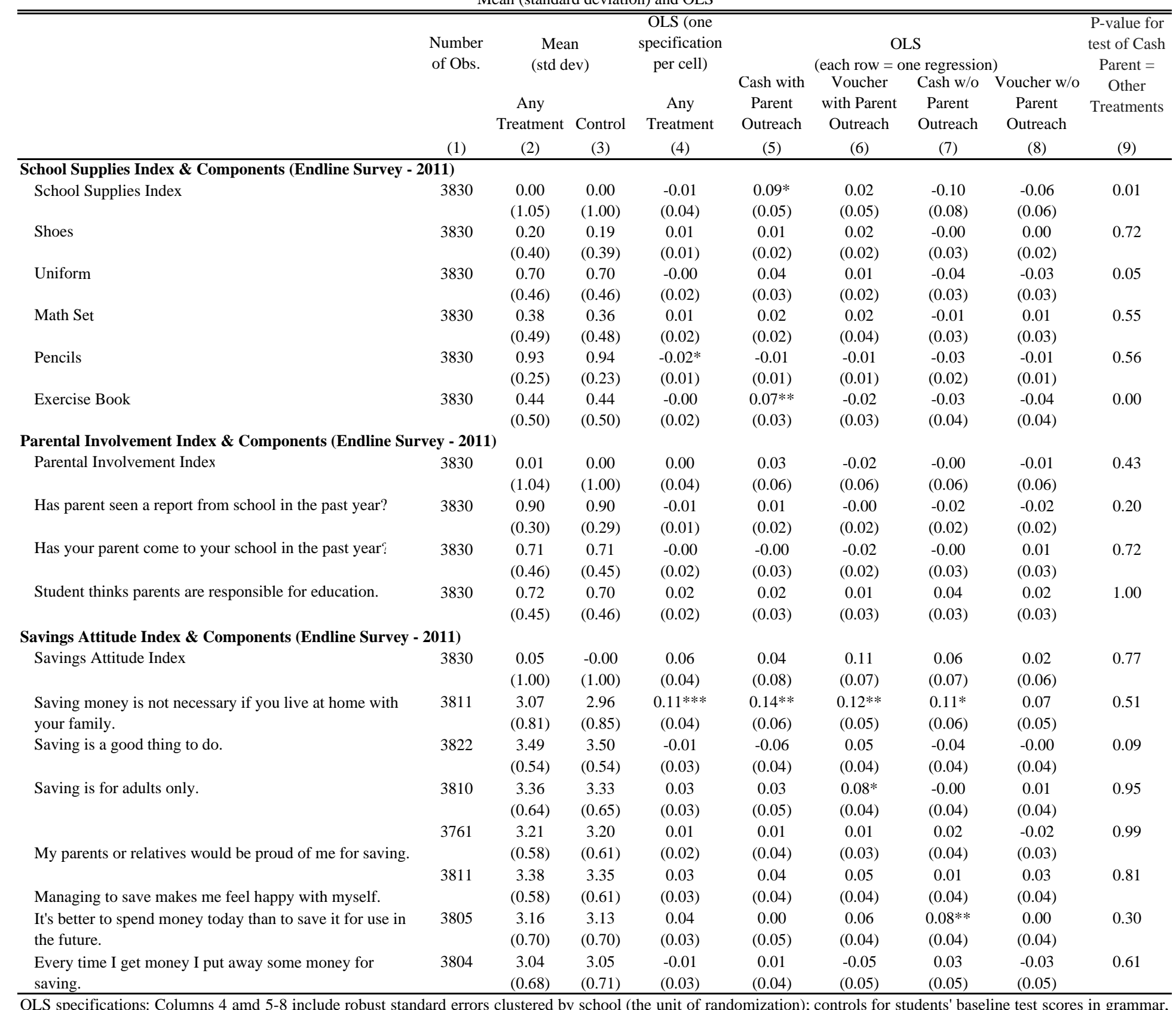

OLS specifications: Columns 4 amd 5-8 include robust standard errors clustered by school (the unit of randomization); controls for students' baseline test scores in grammar, reading, and math; and subcounty fixed effects (the stratification variables). Column 9 is the p-value of an F-test of sigificance on a regression of the cash parent treatment against all other treatments and the same specifications as in Columns $5-8 .{ }^{*} \mathrm{p}<0.10{ }^{* *} \mathrm{p}<0.05{ }^{* * *} \mathrm{p}<0.01$. 
Appendix Table 4c: Components of Table 4, Panel C, Individual School Supplies Items, Endline 2011

Mean (standard deviation) and OLS

\begin{tabular}{|c|c|c|c|c|c|c|c|c|c|}
\hline & \multirow{2}{*}{$\begin{array}{l}\text { Number } \\
\text { of Obs. } \\
\text { (1) }\end{array}$} & \multicolumn{2}{|c|}{$\begin{array}{c}\text { Mean } \\
\text { (std dev) }\end{array}$} & \multirow{2}{*}{$\begin{array}{c}\text { specificatio } \\
\text { n per cell) } \\
\text { Any } \\
\text { Treatment } \\
\text { (4) }\end{array}$} & \multicolumn{4}{|c|}{$\begin{array}{c}\text { OLS } \\
\text { (each row = one regression) }\end{array}$} & \multirow{2}{*}{$\begin{array}{c}\text { P-value for } \\
\text { test of Cash } \\
\text { Parent = Other } \\
\text { Treatments } \\
\text { (9) }\end{array}$} \\
\hline & & $\begin{array}{c}\text { Any } \\
\text { Treatment } \\
\text { (2) }\end{array}$ & $\begin{array}{l}\text { Control } \\
\text { (3) }\end{array}$ & & $\begin{array}{l}\text { Cash with } \\
\text { Parent } \\
\text { Outreach } \\
\text { (5) }\end{array}$ & $\begin{array}{c}\text { Voucher } \\
\text { with Parent } \\
\text { Outreach } \\
\text { (6) }\end{array}$ & $\begin{array}{l}\text { Cash w/o } \\
\text { Parent } \\
\text { Outreach } \\
\text { (7) }\end{array}$ & $\begin{array}{c}\text { Voucher } \\
\text { w/o Parent } \\
\text { Outreach } \\
\text { (8) }\end{array}$ & \\
\hline Reports owning at least 1 pair of shoes & 3830 & $\begin{array}{c}0.63 \\
(0.48)\end{array}$ & $\begin{array}{c}0.62 \\
(0.49)\end{array}$ & $\begin{array}{c}0.00 \\
(0.02)\end{array}$ & $\begin{array}{c}0.00 \\
(0.02)\end{array}$ & $\begin{array}{l}-0.02 \\
(0.03)\end{array}$ & $\begin{array}{c}0.00 \\
(0.03)\end{array}$ & $\begin{array}{c}0.02 \\
(0.03)\end{array}$ & 0.91 \\
\hline Student wearing shoes during survey & 3830 & $\begin{array}{c}0.20 \\
(0.40)\end{array}$ & $\begin{array}{c}0.19 \\
(0.39)\end{array}$ & $\begin{array}{c}0.01 \\
(0.01)\end{array}$ & $\begin{array}{c}0.01 \\
(0.02)\end{array}$ & $\begin{array}{c}0.02 \\
(0.02)\end{array}$ & $\begin{array}{l}-0.00 \\
(0.03)\end{array}$ & $\begin{array}{c}0.00 \\
(0.02)\end{array}$ & 0.72 \\
\hline Reports owning at least 1 uniform & 3829 & $\begin{array}{c}0.84 \\
(0.36)\end{array}$ & $\begin{array}{c}0.86 \\
(0.35)\end{array}$ & $\begin{array}{l}-0.02 \\
(0.02)\end{array}$ & $\begin{array}{c}0.01 \\
(0.02)\end{array}$ & $\begin{array}{c}0.00 \\
(0.02)\end{array}$ & $\begin{array}{l}-0.05^{* *} \\
(0.02)\end{array}$ & $\begin{array}{l}-0.04^{*} \\
(0.02)\end{array}$ & 0.09 \\
\hline Child wearing uniform during interview & 3830 & $\begin{array}{c}0.70 \\
(0.46)\end{array}$ & $\begin{array}{c}0.70 \\
(0.46)\end{array}$ & $\begin{array}{l}-0.00 \\
(0.02)\end{array}$ & $\begin{array}{c}0.04 \\
(0.03)\end{array}$ & $\begin{array}{c}0.01 \\
(0.02)\end{array}$ & $\begin{array}{l}-0.04 \\
(0.03)\end{array}$ & $\begin{array}{l}-0.03 \\
(0.03)\end{array}$ & 0.05 \\
\hline Reports owning a math set & 3830 & $\begin{array}{c}0.38 \\
(0.49)\end{array}$ & $\begin{array}{c}0.36 \\
(0.48)\end{array}$ & $\begin{array}{c}0.01 \\
(0.02)\end{array}$ & $\begin{array}{c}0.02 \\
(0.02)\end{array}$ & $\begin{array}{c}0.02 \\
(0.04)\end{array}$ & $\begin{array}{l}-0.01 \\
(0.03)\end{array}$ & $\begin{array}{c}0.01 \\
(0.03)\end{array}$ & 0.55 \\
\hline Shows enumerator a math set & 3830 & $\begin{array}{c}0.24 \\
(0.42)\end{array}$ & $\begin{array}{c}0.21 \\
(0.41)\end{array}$ & $\begin{array}{c}0.02 \\
(0.02)\end{array}$ & $\begin{array}{c}0.05^{* *} \\
(0.02)\end{array}$ & $\begin{array}{c}0.04 \\
(0.03)\end{array}$ & $\begin{array}{l}-0.01 \\
(0.03)\end{array}$ & $\begin{array}{c}0.02 \\
(0.03)\end{array}$ & 0.18 \\
\hline Reports owning at least 1 pen or pencil & 3830 & $\begin{array}{c}0.93 \\
(0.25)\end{array}$ & $\begin{array}{c}0.94 \\
(0.23)\end{array}$ & $\begin{array}{l}-0.02 * \\
(0.01)\end{array}$ & $\begin{array}{l}-0.01 \\
(0.01)\end{array}$ & $\begin{array}{l}-0.01 \\
(0.01)\end{array}$ & $\begin{array}{l}-0.03 \\
(0.02)\end{array}$ & $\begin{array}{l}-0.01 \\
(0.01)\end{array}$ & 0.56 \\
\hline Shows enumerator at least 1 pen or pencil & 3830 & $\begin{array}{c}0.82 \\
(0.38)\end{array}$ & $\begin{array}{c}0.82 \\
(0.38)\end{array}$ & $\begin{array}{l}-0.01 \\
(0.01)\end{array}$ & $\begin{array}{l}-0.00 \\
(0.02)\end{array}$ & $\begin{array}{c}0.00 \\
(0.02)\end{array}$ & $\begin{array}{l}-0.03 \\
(0.03)\end{array}$ & $\begin{array}{c}0.00 \\
(0.02)\end{array}$ & 0.80 \\
\hline Reports owning $>6$ exercise books & 3830 & $\begin{array}{c}0.44 \\
(0.50)\end{array}$ & $\begin{array}{c}0.44 \\
(0.50)\end{array}$ & $\begin{array}{l}-0.00 \\
(0.02)\end{array}$ & $\begin{array}{l}0.07 * * \\
(0.03)\end{array}$ & $\begin{array}{l}-0.02 \\
(0.03)\end{array}$ & $\begin{array}{l}-0.03 \\
(0.04)\end{array}$ & $\begin{array}{l}-0.04 \\
(0.04)\end{array}$ & 0.00 \\
\hline Shows enumerator $>6$ exercise books & 3830 & $\begin{array}{c}0.31 \\
(0.46)\end{array}$ & $\begin{array}{c}0.32 \\
(0.47)\end{array}$ & $\begin{array}{l}-0.01 \\
(0.02)\end{array}$ & $\begin{array}{c}0.04 \\
(0.03)\end{array}$ & $\begin{array}{l}-0.01 \\
(0.03)\end{array}$ & $\begin{array}{l}-0.04 \\
(0.03)\end{array}$ & $\begin{array}{l}-0.02 \\
(0.03)\end{array}$ & 0.00 \\
\hline
\end{tabular}

OLS specifications: Columns 4 amd 5-8 include robust standard errors clustered by school (the unit of randomization); controls for students' baseline test scores in grammar, reading, and math; and subcounty fixed effects (the stratification variables). Column 9 is the p-value of an F-test of sigificance on a regression of the cash parent treatment against all other treatments and the same specifications as in Columns 5-8. ${ }^{*} \mathrm{p}<0.10 * * \mathrm{p}<0.05 * * * \mathrm{p}<0.01$. 
Appendix Table 4d: Components of Table 6, Attendence Index, Endline 2011

Mean (standard deviation) and OLS

\begin{tabular}{|c|c|c|c|c|c|c|c|c|c|}
\hline & \multirow{2}{*}{$\begin{array}{c}\text { Number } \\
\text { of Obs. } \\
\\
\text { (1) }\end{array}$} & \multicolumn{2}{|c|}{$\begin{array}{c}\text { Mean } \\
\text { (std dev) }\end{array}$} & \multirow{2}{*}{$\begin{array}{c}\text { OLS (one } \\
\text { specification } \\
\text { per cell) } \\
\\
\text { Any } \\
\text { Treatment } \\
(4) \\
\end{array}$} & \multicolumn{4}{|c|}{$\begin{array}{c}\text { OLS } \\
\text { (each row }=\text { one regression) }\end{array}$} & \multirow{2}{*}{$\begin{array}{c}\text { P-value for } \\
\text { test of Cash } \\
\text { Parent }= \\
\text { Other } \\
\text { Treatments } \\
\\
\text { (9) } \\
\end{array}$} \\
\hline & & $\begin{array}{c}\text { Any } \\
\text { Treatment } \\
(2)\end{array}$ & $\begin{array}{c}\text { Control } \\
\text { (3) }\end{array}$ & & $\begin{array}{l}\text { Cash with } \\
\text { Parent } \\
\text { Outreach } \\
\text { (5) }\end{array}$ & $\begin{array}{c}\text { Voucher } \\
\text { with Parent } \\
\text { Outreach } \\
(6)\end{array}$ & $\begin{array}{c}\text { Cash w/o } \\
\text { Parent } \\
\text { Outreach } \\
(7) \\
\end{array}$ & $\begin{array}{c}\text { Voucher } \\
\text { w/o Parent } \\
\text { Outreach } \\
\text { (8) }\end{array}$ & \\
\hline \multicolumn{10}{|c|}{ Attendance Index \& Components (Endline Survey - 2011) } \\
\hline Attendance Index & 3578 & $\begin{array}{l}-0.02 \\
(0.98)\end{array}$ & $\begin{array}{l}-0.00 \\
(1.00)\end{array}$ & $\begin{array}{l}-0.02 \\
(0.04)\end{array}$ & $\begin{array}{c}0.02 \\
(0.06)\end{array}$ & $\begin{array}{c}0.00 \\
(0.06)\end{array}$ & $\begin{array}{l}-0.05 \\
(0.06)\end{array}$ & $\begin{array}{l}-0.03 \\
(0.06)\end{array}$ & 0.24 \\
\hline Of five school days of last week, was absent for & 3577 & $\begin{array}{c}0.75 \\
(1.33)\end{array}$ & $\begin{array}{c}0.70 \\
(1.27)\end{array}$ & $\begin{array}{c}0.05 \\
(0.06)\end{array}$ & $\begin{array}{c}0.13 \\
(0.11)\end{array}$ & $\begin{array}{c}0.07 \\
(0.08)\end{array}$ & $\begin{array}{c}0.03 \\
(0.09)\end{array}$ & $\begin{array}{l}-0.03 \\
(0.08)\end{array}$ & 0.35 \\
\hline $\begin{array}{l}\text { In normal week from last term, how many days were } \\
\text { you usually absent from school? }\end{array}$ & 3578 & $\begin{array}{c}1.27 \\
(1.48)\end{array}$ & $\begin{array}{c}1.31 \\
(1.54)\end{array}$ & $\begin{array}{l}-0.02 \\
(0.07)\end{array}$ & $\begin{array}{l}-0.00 \\
(0.08)\end{array}$ & $\begin{array}{l}-0.01 \\
(0.08)\end{array}$ & $\begin{array}{l}-0.04 \\
(0.10)\end{array}$ & $\begin{array}{l}-0.03 \\
(0.10)\end{array}$ & 0.45 \\
\hline $\begin{array}{l}\text { Think of a normal month from last term, how many } \\
\text { days were you usually absent? }\end{array}$ & 3455 & $\begin{array}{c}3.34 \\
(3.13) \\
\end{array}$ & $\begin{array}{c}3.59 \\
(3.55) \\
\end{array}$ & $\begin{array}{l}-0.24 * \\
(0.13) \\
\end{array}$ & $\begin{array}{l}-0.27 \\
(0.17) \\
\end{array}$ & $\begin{array}{c}-0.17 \\
(0.21) \\
\end{array}$ & $\begin{array}{c}-0.38 * * \\
(0.17) \\
\end{array}$ & $\begin{array}{l}-0.17 \\
(0.19) \\
\end{array}$ & 0.80 \\
\hline
\end{tabular}

OLS specifications: Columns 4 amd 5-8 include robust standard errors clustered by school (the unit of randomization); controls for students' baseline test scores in grammar, reading, and math; and subcounty fixed effects (the stratification variables). Column 9 is the p-value of an F-test of sigificance on a regression of the cash parent treatment against all other treatments and the same specifications as in Columns $5-8 .{ }^{*} \mathrm{p}<0.10 * * \mathrm{p}<0.05 * * * \mathrm{p}<0.01$. 
Appendix Table 4e: Components of Table 7, Self Esteem Index, Endline 2011

Mean (standard deviation) and OLS

\begin{tabular}{|c|c|c|c|c|c|c|c|c|c|}
\hline & \multirow{2}{*}{$\begin{array}{c}\text { Number } \\
\text { of Obs. } \\
\text { (1) }\end{array}$} & \multicolumn{2}{|c|}{$\begin{array}{c}\text { Mean } \\
\text { (std dev) }\end{array}$} & \multirow{2}{*}{$\begin{array}{c}\text { OLS (one } \\
\text { specification } \\
\text { per cell) } \\
\text { Any } \\
\text { Treatment } \\
\text { (4) }\end{array}$} & \multicolumn{4}{|c|}{$\begin{array}{c}\text { OLS } \\
\text { (each row = one regression) }\end{array}$} & \multirow{2}{*}{$\begin{array}{c}\text { P-value for } \\
\text { test of Cash } \\
\text { Parent = Other } \\
\text { Treatments } \\
\text { (9) }\end{array}$} \\
\hline & & $\begin{array}{c}\text { Any } \\
\text { Treatment } \\
(2) \\
\end{array}$ & $\begin{array}{c}\text { Control } \\
(3)\end{array}$ & & $\begin{array}{l}\text { Cash with } \\
\text { Parent } \\
\text { Outreach } \\
(5) \\
\end{array}$ & $\begin{array}{c}\text { Voucher with } \\
\text { Parent } \\
\text { Outreach } \\
(6) \\
\end{array}$ & $\begin{array}{l}\text { Cash w/o } \\
\text { Parent } \\
\text { Outreach } \\
(7) \\
\end{array}$ & $\begin{array}{c}\text { Voucher } \\
\text { w/o Parent } \\
\text { Outreach } \\
\text { (8) }\end{array}$ & \\
\hline \multicolumn{10}{|c|}{ Self Esteem Index \& Components (Endline Survey - 2011) } \\
\hline Self Esteem Index & 3830 & $\begin{array}{l}-0.02 \\
(0.44)\end{array}$ & $\begin{array}{l}-0.00 \\
(0.44)\end{array}$ & $\begin{array}{l}-0.03 \\
(0.02)\end{array}$ & $\begin{array}{c}-0.05 * * \\
(0.02)\end{array}$ & $\begin{array}{l}-0.03 \\
(0.02)\end{array}$ & $\begin{array}{l}-0.03 \\
(0.03)\end{array}$ & $\begin{array}{l}-0.01 \\
(0.03)\end{array}$ & 0.25 \\
\hline I am satisfied with myself. & 3804 & $\begin{array}{c}3.20 \\
(0.67)\end{array}$ & $\begin{array}{c}3.21 \\
(0.64)\end{array}$ & $\begin{array}{l}-0.01 \\
(0.03)\end{array}$ & $\begin{array}{l}-0.01 \\
(0.05)\end{array}$ & $\begin{array}{l}-0.01 \\
(0.04)\end{array}$ & $\begin{array}{l}-0.01 \\
(0.04)\end{array}$ & $\begin{array}{l}-0.02 \\
(0.05)\end{array}$ & 0.94 \\
\hline Sometimes I think I am no good at all. & 3809 & $\begin{array}{c}2.55 \\
(0.79)\end{array}$ & $\begin{array}{c}2.54 \\
(0.77)\end{array}$ & $\begin{array}{l}-0.00 \\
(0.03)\end{array}$ & $\begin{array}{l}-0.05 \\
(0.04)\end{array}$ & $\begin{array}{c}0.01 \\
(0.05)\end{array}$ & $\begin{array}{c}0.00 \\
(0.04)\end{array}$ & $\begin{array}{c}0.03 \\
(0.05)\end{array}$ & 0.09 \\
\hline I believe I have a number of good qualities. & 3792 & $\begin{array}{c}3.14 \\
(0.71)\end{array}$ & $\begin{array}{c}3.19 \\
(0.69)\end{array}$ & $\begin{array}{c}-0.06 * * \\
(0.03)\end{array}$ & $\begin{array}{l}-0.08 \\
(0.05)\end{array}$ & $\begin{array}{l}-0.08 * \\
(0.04)\end{array}$ & $\begin{array}{l}-0.04 \\
(0.03)\end{array}$ & $\begin{array}{l}-0.04 \\
(0.05)\end{array}$ & 0.68 \\
\hline I am able to do things as well as most children. & 3814 & $\begin{array}{c}3.31 \\
(0.62)\end{array}$ & $\begin{array}{c}3.33 \\
(0.62)\end{array}$ & $\begin{array}{l}-0.03 \\
(0.02)\end{array}$ & $\begin{array}{l}-0.05^{*} \\
(0.03)\end{array}$ & $\begin{array}{l}-0.01 \\
(0.03)\end{array}$ & $\begin{array}{l}-0.03 \\
(0.04)\end{array}$ & $\begin{array}{l}-0.04 \\
(0.04)\end{array}$ & 0.37 \\
\hline I do not have much to be proud of. & 3769 & $\begin{array}{c}2.42 \\
(0.77)\end{array}$ & $\begin{array}{c}2.43 \\
(0.78)\end{array}$ & $\begin{array}{l}-0.01 \\
(0.03)\end{array}$ & $\begin{array}{c}0.03 \\
(0.05)\end{array}$ & $\begin{array}{l}-0.07 \\
(0.04)\end{array}$ & $\begin{array}{l}-0.01 \\
(0.05)\end{array}$ & $\begin{array}{c}0.02 \\
(0.05)\end{array}$ & 0.23 \\
\hline Sometimes I feel useless. & 3808 & $\begin{array}{c}3.08 \\
(0.80)\end{array}$ & $\begin{array}{c}3.08 \\
(0.81)\end{array}$ & $\begin{array}{l}-0.01 \\
(0.03)\end{array}$ & $\begin{array}{l}-0.05 \\
(0.03)\end{array}$ & $\begin{array}{l}-0.01 \\
(0.04)\end{array}$ & $\begin{array}{c}0.05 \\
(0.04)\end{array}$ & $\begin{array}{l}-0.02 \\
(0.04)\end{array}$ & 0.05 \\
\hline $\begin{array}{l}\text { I believe I am a valuable person, at least as } \\
\text { much as my classmates. }\end{array}$ & 3800 & $\begin{array}{l}3.25 \\
(0.62)\end{array}$ & $\begin{array}{l}3.28 \\
(0.64)\end{array}$ & $\begin{array}{l}-0.04 \\
(0.03)\end{array}$ & $\begin{array}{l}-0.07^{*} \\
(0.04)\end{array}$ & $\begin{array}{c}0.01 \\
(0.04)\end{array}$ & $\begin{array}{l}-0.06 \\
(0.04)\end{array}$ & $\begin{array}{l}-0.04 \\
(0.04)\end{array}$ & 0.37 \\
\hline I wish I could have more respect for myself. & 3747 & $\begin{array}{c}1.96 \\
(0.62)\end{array}$ & $\begin{array}{c}1.94 \\
(0.61)\end{array}$ & $\begin{array}{c}0.01 \\
(0.03)\end{array}$ & $\begin{array}{c}0.03 \\
(0.04)\end{array}$ & $\begin{array}{l}-0.06 \\
(0.05)\end{array}$ & $\begin{array}{c}0.05 \\
(0.04)\end{array}$ & $\begin{array}{c}0.02 \\
(0.04)\end{array}$ & 0.64 \\
\hline I sometimes think that I am a failure. & 3806 & $\begin{array}{c}2.98 \\
(0.84)\end{array}$ & $\begin{array}{c}2.96 \\
(0.86)\end{array}$ & $\begin{array}{c}0.02 \\
(0.03)\end{array}$ & $\begin{array}{l}-0.03 \\
(0.04)\end{array}$ & $\begin{array}{c}0.04 \\
(0.04)\end{array}$ & $\begin{array}{l}-0.04 \\
(0.04)\end{array}$ & $\begin{array}{l}0.09 * * \\
(0.04)\end{array}$ & 0.12 \\
\hline $\begin{array}{l}\text { When I think of myself, I usually think good } \\
\text { thoughts. }\end{array}$ & 3820 & $\begin{array}{c}2.96 \\
(0.81)\end{array}$ & $\begin{array}{c}2.98 \\
(0.82)\end{array}$ & $\begin{array}{l}-0.03 \\
(0.03)\end{array}$ & $\begin{array}{l}-0.04 \\
(0.05)\end{array}$ & $\begin{array}{c}0.01 \\
(0.05)\end{array}$ & $\begin{array}{c}-0.10^{* *} \\
(0.04)\end{array}$ & $\begin{array}{c}0.01 \\
(0.05)\end{array}$ & 0.84 \\
\hline $\begin{array}{l}\text { Are you confident that you will be successful in } \\
\text { the future? }\end{array}$ & 3645 & $\begin{array}{c}0.96 \\
(0.21)\end{array}$ & $\begin{array}{c}0.97 \\
(0.18)\end{array}$ & $\begin{array}{l}-0.01^{*} \\
(0.01)\end{array}$ & $\begin{array}{l}-0.01 \\
(0.01)\end{array}$ & $\begin{array}{c}-0.02 * * \\
(0.01)\end{array}$ & $\begin{array}{l}-0.01 \\
(0.01)\end{array}$ & $\begin{array}{l}-0.01 \\
(0.01)\end{array}$ & 0.95 \\
\hline
\end{tabular}

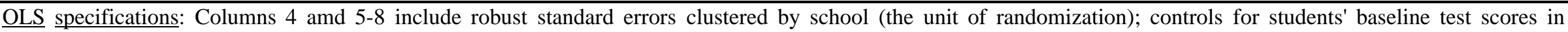

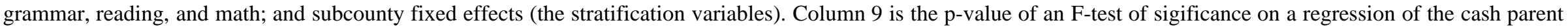
treatment against all other treatments and the same specifications as in Columns $5-8 .{ }^{*} \mathrm{p}<0.10{ }^{* *} \mathrm{p}<0.05 * * * \mathrm{p}<0.01$. 
Appendix Table 4f: Components of Table 7, Time Preference, Financial Independence, and Aspirations Indices, Endline 2011 Mean (standard deviation) and OLS

\begin{tabular}{|c|c|c|c|c|c|c|c|c|c|}
\hline & $\begin{array}{l}\text { Number } \\
\text { of Obs. }\end{array}$ & $\begin{array}{r}\mathrm{M} \\
\text { (std }\end{array}$ & an & $\begin{array}{l}\text { OLS (one } \\
\text { specification } \\
\text { per cell) }\end{array}$ & & $\begin{array}{r}\mathrm{OL} \\
\text { (each row }=\text { on }\end{array}$ & $\begin{array}{l}\mathrm{S} \\
\text { e regressior }\end{array}$ & & $\begin{array}{c}\text { P-value for } \\
\text { test of Cash } \\
\text { Parent = Other }\end{array}$ \\
\hline & $(1)$ & $\begin{array}{c}\text { Any } \\
\text { Treatment } \\
(2) \\
\end{array}$ & $\begin{array}{c}\text { Control } \\
(3)\end{array}$ & $\begin{array}{c}\text { Any } \\
\text { Treatment } \\
(4) \\
\end{array}$ & $\begin{array}{l}\text { Cash with } \\
\text { Parent } \\
\text { Outreach } \\
\text { (5) } \\
\end{array}$ & $\begin{array}{c}\text { Voucher with } \\
\text { Parent } \\
\text { Outreach } \\
(6) \\
\end{array}$ & $\begin{array}{c}\text { Cash w/o } \\
\text { Parent } \\
\text { Outreach } \\
(7) \\
\end{array}$ & $\begin{array}{c}\text { Voucher } \\
\text { w/o Parent } \\
\text { Outreach } \\
(8)\end{array}$ & $\begin{array}{c}\text { Treatments } \\
\\
\text { (9) } \\
\end{array}$ \\
\hline Time Preference Index \& Components (Endline Sur & vey - 2011 & & & & & & & & \\
\hline Time Preference Index & 3820 & $\begin{array}{c}2.05 \\
(0.83)\end{array}$ & $\begin{array}{c}2.07 \\
(0.82)\end{array}$ & $\begin{array}{l}-0.02 \\
(0.03)\end{array}$ & $\begin{array}{l}-0.02 \\
(0.04)\end{array}$ & $\begin{array}{l}-0.02 \\
(0.04)\end{array}$ & $\begin{array}{l}-0.00 \\
(0.04)\end{array}$ & $\begin{array}{l}-0.03 \\
(0.04)\end{array}$ & 0.99 \\
\hline $\begin{array}{l}\text { Would you rather receive } 500 \text { UGX today or } 800 \\
\text { UGX next week? }\end{array}$ & 3820 & $\begin{array}{l}1.37 \\
(0.48)\end{array}$ & $\begin{array}{l}1.37 \\
(0.48)\end{array}$ & $\begin{array}{l}-0.00 \\
(0.02)\end{array}$ & $\begin{array}{c}0.01 \\
(0.02)\end{array}$ & $\begin{array}{l}-0.01 \\
(0.03)\end{array}$ & $\begin{array}{c}0.01 \\
(0.03)\end{array}$ & $\begin{array}{l}-0.01 \\
(0.03)\end{array}$ & 0.45 \\
\hline $\begin{array}{l}\text { Would you rather receive } 500 \text { UGX today or 1,000 } \\
\text { UGX next week? }\end{array}$ & 2410 & $\begin{array}{c}1.49 \\
(0.50)\end{array}$ & $\begin{array}{c}1.52 \\
(0.50)\end{array}$ & $\begin{array}{l}-0.03 \\
(0.02)\end{array}$ & $\begin{array}{l}-0.06 * \\
(0.03)\end{array}$ & $\begin{array}{l}-0.00 \\
(0.03)\end{array}$ & $\begin{array}{l}-0.02 \\
(0.03)\end{array}$ & $\begin{array}{l}-0.03 \\
(0.03)\end{array}$ & 0.29 \\
\hline Financial Independence Index \& Components (Endl & ine Surve & - 2011) & & & & & & & \\
\hline Financial Independence Index & 3830 & $\begin{array}{l}-0.04 \\
(0.97)\end{array}$ & $\begin{array}{c}0.00 \\
(1.00)\end{array}$ & $\begin{array}{l}-0.03 \\
(0.04)\end{array}$ & $\begin{array}{l}-0.05 \\
(0.06)\end{array}$ & $\begin{array}{c}-0.13^{* *} \\
(0.06)\end{array}$ & $\begin{array}{c}0.06 \\
(0.06)\end{array}$ & $\begin{array}{l}-0.00 \\
(0.05)\end{array}$ & 0.65 \\
\hline $\begin{array}{l}\text { How much money do you think you will get in the } \\
\text { next } 7 \text { days? winsorized at } 99 \%\end{array}$ & 3643 & $\begin{array}{c}2245.60 \\
(4225.71)\end{array}$ & $\begin{array}{c}2399.59 \\
(4587.07)\end{array}$ & $\begin{array}{l}-108.12 \\
(167.45)\end{array}$ & $\begin{array}{l}-198.11 \\
(217.85)\end{array}$ & $\begin{array}{l}-449.73 * \\
(248.81)\end{array}$ & $\begin{array}{c}242.09 \\
(252.49)\end{array}$ & $\begin{array}{c}-18.71 \\
(242.72)\end{array}$ & 0.59 \\
\hline $\begin{array}{l}\text { How much money did you get in the past } 7 \text { days? } \\
\text { winsorized at } 99 \%\end{array}$ & 3830 & $\begin{array}{c}1957.95 \\
(3332.84)\end{array}$ & $\begin{array}{c}2038.95 \\
(3464.53)\end{array}$ & $\begin{array}{c}-50.81 \\
(118.34)\end{array}$ & $\begin{array}{c}-96.29 \\
(194.09)\end{array}$ & $\begin{array}{c}-412.40^{* *} \\
(188.15)\end{array}$ & $\begin{array}{c}308.69 \\
(188.99)\end{array}$ & $\begin{array}{c}1.97 \\
(153.16)\end{array}$ & 0.71 \\
\hline $\begin{array}{l}\text { How much pocket money are you given to spend as } \\
\text { you wish? winsorized at } 99 \%\end{array}$ & 3830 & $\begin{array}{c}4394.88 \\
(7170.65)\end{array}$ & $\begin{array}{c}4584.16 \\
(7246.93)\end{array}$ & $\begin{array}{l}-210.99 \\
(283.78)\end{array}$ & $\begin{array}{l}-346.28 \\
(360.50)\end{array}$ & $\begin{array}{l}-443.56 \\
(415.79)\end{array}$ & $\begin{array}{c}-10.95 \\
(534.00)\end{array}$ & $\begin{array}{c}-49.41 \\
(430.67)\end{array}$ & 0.73 \\
\hline Aspirations Index \& Components (Endline Survey - & 2011) & & & & & & & & \\
\hline Aspirations Index & 3830 & $\begin{array}{l}-0.01 \\
(1.04)\end{array}$ & $\begin{array}{c}0.00 \\
(1.00)\end{array}$ & $\begin{array}{l}-0.03 \\
(0.04)\end{array}$ & $\begin{array}{l}-0.05 \\
(0.06)\end{array}$ & $\begin{array}{l}-0.03 \\
(0.06)\end{array}$ & $\begin{array}{c}0.02 \\
(0.04)\end{array}$ & $\begin{array}{l}-0.04 \\
(0.06)\end{array}$ & 0.54 \\
\hline Do you think you will go to secondary school? & 3691 & $\begin{array}{l}-0.05 \\
(1.11)\end{array}$ & $\begin{array}{l}-0.00 \\
(1.00)\end{array}$ & $\begin{array}{l}-0.06 \\
(0.04)\end{array}$ & $\begin{array}{l}-0.10 \\
(0.06)\end{array}$ & $\begin{array}{l}-0.03 \\
(0.06)\end{array}$ & $\begin{array}{l}-0.00 \\
(0.04)\end{array}$ & $\begin{array}{l}-0.09 \\
(0.06)\end{array}$ & 0.37 \\
\hline Do you think you will reach university? & 3054 & $\begin{array}{l}-0.05 \\
(1.04)\end{array}$ & $\begin{array}{l}-0.00 \\
(1.00)\end{array}$ & $\begin{array}{l}-0.06 \\
(0.04)\end{array}$ & $\begin{array}{l}-0.06 \\
(0.06)\end{array}$ & $\begin{array}{l}-0.10^{*} \\
(0.06)\end{array}$ & $\begin{array}{l}-0.01 \\
(0.06)\end{array}$ & $\begin{array}{l}-0.09 \\
(0.06)\end{array}$ & 0.96 \\
\hline $\begin{array}{l}\text { If you graduate from primary school, will your life } \\
\text { be better than if you hadn't graduated? }\end{array}$ & 3830 & $\begin{array}{c}0.05 \\
(0.94)\end{array}$ & $\begin{array}{l}-0.00 \\
(1.00)\end{array}$ & $\begin{array}{c}0.04 \\
(0.03)\end{array}$ & $\begin{array}{c}0.08 \\
(0.05)\end{array}$ & $\begin{array}{l}-0.00 \\
(0.04)\end{array}$ & $\begin{array}{c}0.06 \\
(0.05)\end{array}$ & $\begin{array}{c}0.04 \\
(0.05)\end{array}$ & 0.26 \\
\hline $\begin{array}{l}\text { What do you want to be when you grow up? } \\
\text { (student responded with career that requires higher } \\
\text { education) }\end{array}$ & 3830 & $\begin{array}{c}0.02 \\
(0.98)\end{array}$ & $\begin{array}{c}0.00 \\
(1.00)\end{array}$ & $\begin{array}{c}0.01 \\
(0.03)\end{array}$ & $\begin{array}{l}-0.05 \\
(0.04)\end{array}$ & $\begin{array}{c}0.05 \\
(0.05)\end{array}$ & $\begin{array}{c}0.00 \\
(0.05)\end{array}$ & $\begin{array}{c}0.01 \\
(0.04)\end{array}$ & 0.08 \\
\hline
\end{tabular}

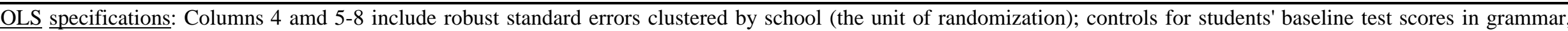

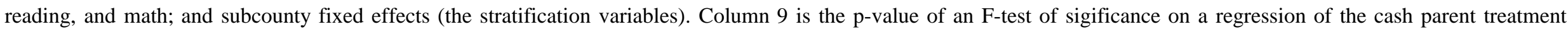
against all other treatments and the same specifications as in Columns 5-8. ${ }^{*} \mathrm{p}<0.10 * * \mathrm{p}<0.05 * * * \mathrm{p}<0.01$. 
Appendix Table 5: Repeat of Table 4, without controls for baseline test scores Mean (standard deviation) and OLS

\begin{tabular}{|c|c|c|c|c|c|c|c|}
\hline Dependent Variables & $\begin{array}{l}\text { Number } \\
\text { of Obs. }\end{array}$ & $\begin{array}{c}\text { OLS (one } \\
\text { specification } \\
\text { per cell) } \\
\text { Any } \\
\text { Treatment } \\
\text { (2) }\end{array}$ & $\begin{array}{l}\text { Cash with } \\
\text { Parent } \\
\text { Outreach } \\
\text { (3) }\end{array}$ & $\begin{array}{l}\text { OL } \\
\text { (each row = on } \\
\text { Voucher } \\
\text { with Parent } \\
\text { Outreach } \\
\text { (4) }\end{array}$ & $\begin{array}{l}\text { LS } \\
\text { ne regression } \\
\text { Cash w/o } \\
\text { Parent } \\
\text { Outreach } \\
\text { (5) }\end{array}$ & $\begin{array}{l}\text { Voucher } \\
\text { w/o Parent } \\
\text { Outreach } \\
\text { (6) }\end{array}$ & $\begin{array}{c}\text { P-value for } \\
\text { test of Cash } \\
\text { Parent }= \\
\text { Other } \\
\text { Treatments } \\
\text { (7) }\end{array}$ \\
\hline \multicolumn{8}{|l|}{ Panel A: Process Outcomes (Endline Survey - 2011) } \\
\hline Heard of Super Savers program & 3831 & $\begin{array}{c}0.67 * * * \\
(0.02)\end{array}$ & $\begin{array}{c}0.69 * * * \\
(0.02)\end{array}$ & $\begin{array}{c}0.67 * * * \\
(0.03)\end{array}$ & $\begin{array}{c}0.69 * * * \\
(0.02)\end{array}$ & $\begin{array}{c}0.64 * * * \\
(0.03)\end{array}$ & 0.26 \\
\hline Ever Talked with Parent about Saving & 3829 & $\begin{array}{c}0.15^{* * * *} \\
(0.02)\end{array}$ & $\begin{array}{c}0.15 * * * \\
(0.03)\end{array}$ & $\begin{array}{c}0.14 * * * \\
(0.03)\end{array}$ & $\begin{array}{c}0.17 * * * \\
(0.03)\end{array}$ & $\begin{array}{c}0.16 * * * \\
(0.03)\end{array}$ & 0.78 \\
\hline Saved with Super Savers & 3832 & $\begin{array}{c}0.40 * * * \\
(0.02)\end{array}$ & $\begin{array}{c}0.42 * * * \\
(0.02)\end{array}$ & $\begin{array}{c}0.39 * * * \\
(0.04)\end{array}$ & $\begin{array}{c}0.44 * * * \\
(0.03)\end{array}$ & $\begin{array}{c}0.35 * * * \\
(0.04)\end{array}$ & 0.37 \\
\hline Ever Saves Money & 3829 & $\begin{array}{c}0.00 \\
(0.02)\end{array}$ & $\begin{array}{c}0.00 \\
(0.02)\end{array}$ & $\begin{array}{c}0.02 \\
(0.03)\end{array}$ & $\begin{array}{c}0.02 \\
(0.03)\end{array}$ & $\begin{array}{l}-0.03 \\
(0.02)\end{array}$ & 0.86 \\
\hline Primary Source of Funds Saved was Work & 3838 & $\begin{array}{c}-0.04 * * \\
(0.02)\end{array}$ & $\begin{array}{c}-0.07 * * \\
(0.03)\end{array}$ & $\begin{array}{l}-0.04 \\
(0.03)\end{array}$ & $\begin{array}{l}-0.00 \\
(0.03)\end{array}$ & $\begin{array}{c}-0.05^{* *} \\
(0.02)\end{array}$ & 0.23 \\
\hline Any Funds Saved Came from Work & 3830 & $\begin{array}{l}-0.04 * \\
(0.02)\end{array}$ & $\begin{array}{l}-0.05^{*} \\
(0.03)\end{array}$ & $\begin{array}{l}-0.04 \\
(0.03)\end{array}$ & $\begin{array}{l}-0.01 \\
(0.03)\end{array}$ & $\begin{array}{c}-0.05^{* *} \\
(0.02)\end{array}$ & 0.69 \\
\hline Any Funds Saved Came from Other Sources & 3830 & $\begin{array}{l}0.03^{*} \\
(0.02)\end{array}$ & $\begin{array}{l}0.05^{*} \\
(0.03)\end{array}$ & $\begin{array}{c}0.04 \\
(0.03)\end{array}$ & $\begin{array}{c}0.02 \\
(0.03)\end{array}$ & $\begin{array}{c}0.02 \\
(0.02)\end{array}$ & 0.34 \\
\hline Number of locations actively used for saving & 3838 & $\begin{array}{c}0.08^{* * *} \\
(0.02)\end{array}$ & $\begin{array}{c}0.08 * * * \\
(0.03)\end{array}$ & $\begin{array}{l}0.10^{* *} \\
(0.04)\end{array}$ & $\begin{array}{l}0.06^{*} \\
(0.04)\end{array}$ & $\begin{array}{c}0.06 * * \\
(0.03)\end{array}$ & 0.70 \\
\hline In-school self-reported savings last term, UGX wins. 95\% & 3838 & $\begin{array}{c}495 * * * \\
(35)\end{array}$ & $\begin{array}{c}531^{* * * *} \\
(60)\end{array}$ & $\begin{array}{c}413^{* * * *} \\
(65)\end{array}$ & $\begin{array}{c}634^{* * * *} \\
(68)\end{array}$ & $\begin{array}{c}408^{* * * *} \\
(60)\end{array}$ & 0.49 \\
\hline Out-of-school self-reported savings last term, UGX wins. 95\% & 3838 & $\begin{array}{c}-1504 * * * \\
(287)\end{array}$ & $\begin{array}{c}-1392 * * * \\
(493)\end{array}$ & $\begin{array}{c}-1719 * * * \\
(458)\end{array}$ & $\begin{array}{c}-1210^{* * *} \\
(456)\end{array}$ & $\begin{array}{c}-1682^{* * * *} \\
(349)\end{array}$ & 0.69 \\
\hline \multicolumn{8}{|l|}{ Panel B: Intermediate Outcomes (Classroom Visits) } \\
\hline School Supplies Index 2010 & 813 & $\begin{array}{c}-0.08 \\
(0.12)\end{array}$ & $\begin{array}{c}0.11 \\
(0.12)\end{array}$ & $\begin{array}{c}-0.06 \\
(0.20)\end{array}$ & $\begin{array}{l}-0.15 \\
(0.22)\end{array}$ & $\begin{array}{c}-0.22 \\
(0.19)\end{array}$ & 0.05 \\
\hline School Supplies Index 2011 & 950 & $\begin{array}{c}0.08 \\
(0.11)\end{array}$ & $\begin{array}{c}0.34 * * \\
(0.13)\end{array}$ & $\begin{array}{c}0.04 \\
(0.18)\end{array}$ & $\begin{array}{l}-0.09 \\
(0.19)\end{array}$ & $\begin{array}{c}0.04 \\
(0.15)\end{array}$ & 0.01 \\
\hline \multicolumn{8}{|l|}{ Panel C: Student Survey (Endline Survey - 2011) } \\
\hline School Supplies Index & 3838 & $\begin{array}{c}0.01 \\
(0.05)\end{array}$ & $\begin{array}{c}0.10 \\
(0.07)\end{array}$ & $\begin{array}{c}0.01 \\
(0.06)\end{array}$ & $\begin{array}{l}-0.07 \\
(0.09)\end{array}$ & $\begin{array}{c}-0.01 \\
(0.05)\end{array}$ & 0.08 \\
\hline Parental Involvement Index & 3838 & $\begin{array}{c}0.01 \\
(0.04)\end{array}$ & $\begin{array}{c}0.04 \\
(0.06)\end{array}$ & $\begin{array}{c}-0.02 \\
(0.06)\end{array}$ & $\begin{array}{c}0.01 \\
(0.06)\end{array}$ & $\begin{array}{c}0.00 \\
(0.06)\end{array}$ & 0.41 \\
\hline Savings Attitude Index & 3838 & $\begin{array}{c}0.06 \\
(0.05)\end{array}$ & $\begin{array}{c}0.04 \\
(0.08)\end{array}$ & $\begin{array}{c}0.10 \\
(0.07)\end{array}$ & $\begin{array}{c}0.07 \\
(0.07)\end{array}$ & $\begin{array}{c}0.02 \\
(0.06)\end{array}$ & 0.76 \\
\hline School Fees & 3532 & $\begin{array}{l}-3600 \\
(2892)\end{array}$ & $\begin{array}{l}-2493 \\
(3063)\end{array}$ & $\begin{array}{c}-6166 \\
(4108)\end{array}$ & $\begin{array}{c}-2406 \\
(3823)\end{array}$ & $\begin{array}{l}-3400 \\
(3816)\end{array}$ & 0.80 \\
\hline Primarily Used Money Earned for School Fees or Supplies & 3838 & $\begin{array}{l}0.02^{*} \\
(0.01)\end{array}$ & $\begin{array}{c}0.02 \\
(0.02)\end{array}$ & $\begin{array}{c}0.02 \\
(0.02)\end{array}$ & $\begin{array}{c}0.03 \\
(0.02)\end{array}$ & $\begin{array}{c}0.02 \\
(0.02)\end{array}$ & 0.95 \\
\hline Student Spent Savings on School Fees,Supplies, or Lunch & 3824 & $\begin{array}{c}0.07 * * * \\
(0.02)\end{array}$ & $\begin{array}{c}0.09 * * * \\
(0.03)\end{array}$ & $\begin{array}{c}0.11 * * * \\
(0.03)\end{array}$ & $\begin{array}{l}0.05^{* *} \\
(0.03)\end{array}$ & $\begin{array}{c}0.04 \\
(0.03)\end{array}$ & 0.45 \\
\hline $\begin{array}{l}\text { Missed school because sent to look for fees or lack of } \\
\text { scholastic materials }\end{array}$ & 3582 & $\begin{array}{c}-0.00 \\
(0.01)\end{array}$ & $\begin{array}{c}-0.01 \\
(0.02)\end{array}$ & $\begin{array}{l}-0.00 \\
(0.02)\end{array}$ & $\begin{array}{c}0.02 \\
(0.02)\end{array}$ & $\begin{array}{r}-0.01 \\
(0.02)\end{array}$ & 0.68 \\
\hline Cost of most recent test & 2348 & $\begin{array}{c}-34 \\
(190)\end{array}$ & $\begin{array}{c}-68 \\
(266)\end{array}$ & $\begin{array}{c}92 \\
(267)\end{array}$ & $\begin{array}{l}-267 \\
(245)\end{array}$ & $\begin{array}{c}86 \\
(306)\end{array}$ & 0.93 \\
\hline
\end{tabular}

avilable, a control for the

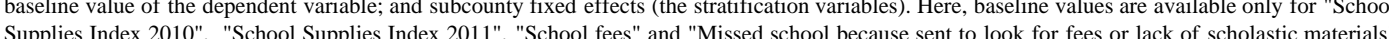
variables. Column 7 is the $p$-value of an $F$-test of sigificance on a regression of the cash parent treatment against all other treatments and the same

specifications as in Columns 3-6. UGX = Ugandan Shillings, 1 USD $=2815$ UGX $*$ p $<0.10 * * \mathrm{p}<0.05 * * * \mathrm{p}<0.01$ 
Appendix Table 6: Repeat of Table 5, without controls for baseline test scores Mean (standard deviation) and OLS

\begin{tabular}{|c|c|c|c|c|c|c|c|}
\hline & $\begin{array}{c}\text { Number of } \\
\text { Obs. }\end{array}$ & $\begin{array}{c}\text { OLS (one } \\
\text { specification } \\
\text { per cell) }\end{array}$ & & $\begin{array}{r}\mathrm{OI} \\
\text { (each row }=0\end{array}$ & regression) & & $\begin{array}{c}\text { P-value for test } \\
\text { of Cash Parent = } \\
\text { Other }\end{array}$ \\
\hline & (1) & $\begin{array}{c}\text { Any } \\
\text { Treatment } \\
\text { (2) }\end{array}$ & $\begin{array}{l}\text { Cash with } \\
\text { Parent } \\
\text { Outreach } \\
\text { (3) }\end{array}$ & $\begin{array}{c}\text { Voucher with } \\
\text { Parent } \\
\text { Outreach } \\
\text { (4) }\end{array}$ & $\begin{array}{l}\text { Cash w/o } \\
\text { Parent } \\
\text { Outreach } \\
\text { (5) }\end{array}$ & $\begin{array}{l}\text { Voucher w/o } \\
\text { Parent } \\
\text { Outreach } \\
\text { (6) }\end{array}$ & Treatments \\
\hline Grammar & 3768 & $\begin{array}{c}0.08 \\
(0.06)\end{array}$ & $\begin{array}{l}0.18^{*} \\
(0.09)\end{array}$ & $\begin{array}{c}0.01 \\
(0.08)\end{array}$ & $\begin{array}{c}0.12 \\
(0.08)\end{array}$ & $\begin{array}{c}0.01 \\
(0.08)\end{array}$ & 0.17 \\
\hline Reading & 3765 & $\begin{array}{c}0.05 \\
(0.06)\end{array}$ & $\begin{array}{c}0.14 \\
(0.10)\end{array}$ & $\begin{array}{l}-0.01 \\
(0.09)\end{array}$ & $\begin{array}{c}0.02 \\
(0.08)\end{array}$ & $\begin{array}{c}0.03 \\
(0.08)\end{array}$ & 0.17 \\
\hline Math & 3768 & $\begin{array}{l}-0.02 \\
(0.05)\end{array}$ & $\begin{array}{c}0.03 \\
(0.08)\end{array}$ & $\begin{array}{l}-0.12 \\
(0.08)\end{array}$ & $\begin{array}{c}0.04 \\
(0.06)\end{array}$ & $\begin{array}{l}-0.03 \\
(0.07)\end{array}$ & 0.36 \\
\hline Total & 3765 & $\begin{array}{c}0.04 \\
(0.06)\end{array}$ & $\begin{array}{c}0.14 \\
(0.09)\end{array}$ & $\begin{array}{l}-0.04 \\
(0.09)\end{array}$ & $\begin{array}{c}0.07 \\
(0.08)\end{array}$ & $\begin{array}{c}0.01 \\
(0.08)\end{array}$ & 0.18 \\
\hline
\end{tabular}

OLS specifications: Columns 2 amd 3-6 include robust standard errors clustered by school (the unit of randomization) and subcounty fixed effects (the stratification variables). Column 7 is the p-value of an F-test of sigificance on a regression of the cash parent treatment against all other treatments and the same specifications as in Columns 3-6. ${ }^{*} \mathrm{p}<0.10{ }^{* *} \mathrm{p}<0.05$ $* * * \mathrm{p}<0.01$ 